\title{
A Paleo-perspective on Ocean Heat Content: Lessons from the Holocene and Common Era
}

Yair Rosenthal ${ }^{1 *}$, Julie Kalansky ${ }^{2}$, Audrey Morley ${ }^{3}$, Braddock Linsley ${ }^{4}$

Revised manuscript for Quaternary Sciences Reviews 


\section{Abstract}

27 The ocean constitutes the largest heat reservoir in the Earth's energy budget and thus 28 exerts a major influence on its climate. Instrumental observations show an increase in 29 ocean heat content $(\mathrm{OHC})$ associated with the increase in greenhouse emissions. Here we

30 review proxy records of intermediate water temperatures from sediment cores in the 31 equatorial Pacific and northeastern Atlantic Oceans, spanning 10,000 years beyond the

32 instrumental record. These records suggests that intermediate waters were $1.5-2{ }^{\circ} \mathrm{C}$

33 warmer during the Holocene Thermal Maximum than in the last century. Intermediate

34 water masses cooled by $0.9^{\circ} \mathrm{C}$ from the Medieval Climate Anomaly to the Little Ice Age.

35 These changes are significantly larger than the temperature anomalies documented in the

36 instrumental record. The implied large perturbations in $\mathrm{OHC}$ and Earth's energy budget

37 may seem at odds with very small radiative forcing anomalies throughout the Holocene

38 and Common Era. We suggest that even very small radiative perturbations can change

39 the latitudinal temperature gradient and strongly affect prevailing atmospheric wind

40 systems and hence air-sea heat exchange. These dynamic processes provide an efficient

41 mechanism to amplify small changes in insolation into relatively large changes in OHC.

42 Over long time periods the ocean's interior acts like a capacitor and builds up large

43 (positive and negative) heat anomalies that can mitigate or amplify small radiative

44 perturbations as seen in the Holocene trend and Common Era anomalies, respectively.

45 Evidently the ocean's interior is more sensitive to small external forcings than the global

46 surface ocean because of the high sensitivity of heat exchange in the high-latitudes to

47 climate variations.

\section{Introduction}

50 The debate about the apparent slow down in the rate of global surface warming during

51 the 1999-2013 decade despite the unabated rise in greenhouse gas (GHG) emissions has

52 brought more attention to the role of the ocean in climate change both among scientists

53 and the general public. The ocean constitutes the largest heat reservoir in the Earth's

54 energy budget due to the high heat capacity of water and large volume and thus play an

55 important role in mediating the Earth's climate (Levitus et al., 2012). Ongoing research 
56 suggests that an increased rate of heat uptake by the ocean's interior may have negated

57 some of the surface warming thereby arguably leading to the apparent slow down in the 58 rate of global warming (e.g., (Balmaseda et al., 2013; Levitus et al., 2012; Meehl et al.,

59 2013; Trenberth and Fasullo, 2013) (Fig. 1). Modern estimates of the change in ocean

60 heat content (OHC) go back only to 1955, however the accuracy of the early data sets is

61 debated (https://www.nodc.noaa.gov/OC5/3M_HEAT_CONTENT/). Since 2006 more

62 accurate estimates have become available from the ARGO array, and they are generally

63 consistent with estimates from the early observations suggesting a relatively constant rate

64 of OHC increase since the early 1990s (Roemmich et al., 2015). A recent compilation

65 suggests that since $1955, \sim 90 \%$ of the excess heat went into the ocean raising concerns

66 about the future state of the oceans (Laffoley and Baxter, 2016). However, given the

67 small magnitude, the brevity of the observed changes in deep OHC and uncertainties in

68 the spatial extent of the current anomalies, any future projection depends on our

69 understanding of the mechanisms controlling changes in the ocean's interior heat content.

70 While ocean heat uptake is directly related to the radiative forcing and climate

71 sensitivity (e.g., (Hansen et al., 1984)), the rate of heat uptake/release by the ocean is

72 dependent, to a large extent, on dynamic processes controlling air-sea exchange at key

73 locations. The exact nature of these processes is, however, debated. For example, it is still

74 unclear if the largest contribution to the current increase in $\mathrm{OHC}$ is due to dynamic

75 changes in the equatorial or the higher latitude oceans.

76 There is mounting evidence that multiple mechanisms are driving the Pacific Decadal

77 Oscillation (PDO) and that some of these processes are also sensitive and/or related to

78 Pacific OHC (e.g., (Balmaseda et al., 2013; England et al., 2014; Meehl et al., 2013;

79 Newman et al., 2016; Thompson et al., 2015; Trenberth and Fasullo, 2013). While the

80 mechanisms controlling the variability of the PDO are still investigated, their global-scale

81 importance is now recognized with the realization that decadal-scale anomalies in surface

82 temperatures, trade winds, sea level pressure and rainfall in the Pacific basin that have

83 developed since the start of the recent hiatus in Earth surface warming ( 1999) resemble

84 the negative phase of the PDO (Trenberth and Fasullo, 2013). During this current

85 negative phase of the PDO, the North and South Pacific central gyres and western

86 equatorial Pacific are warmer than average, while the eastern equatorial Pacific is cooler 
87 than average (Balmaseda et al., 2013; Meehl et al., 2013; Trenberth and Fasullo, 2013;

88 Trenberth et al., 2014). Recent modeling efforts in conjunction with analysis of ARGO

89 float data indicate elevated heat storage in the Pacific water column during this most

90 recent negative phase of the PDO (Balmaseda et al., 2013; England et al., 2014; Kosaka

91 and Xie, 2013; Meehl et al., 2013; Roemmich et al., 2015; Trenberth and Fasullo, 2013)

92 supporting the arguments that the tropical and mid-latitude regions of the Pacific Ocean

93 are important sites of heat exchange between the ocean and the atmosphere. In the

94 subtropics of the Pacific and Atlantic, surface waters can seasonally descend away from

95 the surface along isopycnal surfaces to sub-thermocline depths and flow towards the

96 equator. This process is referred to as the shallow meridional overturning cell. An

97 unprecedented strengthening of the Pacific Ocean shallow overturning cells related to

98 trade wind strengthening has been suggested as the primary cause of the enhanced

99 oceanic heat gain via this subtropical route (Balmaseda et al., 2013; England et al., 2014;

100 Trenberth and Fasullo, 2013). Stronger trade winds coupled with changes in ocean

101 circulation associated with the PDO phase switch in 1999-2000 have resulted in a cooling

102 of the equatorial surface ocean over the last 15 years (England et al., 2014; Trenberth and

103 Fasullo, 2013).

104 Equatorial processes mainly affect the heat content of the thermocline and may also 105 affect the upper water column (0-700m). However, a significant amount of warming $106(\sim 30 \%)$ is observed at intermediate ocean depths (Balmaseda et al., 2013; Roemmich et 107 al., 2015). This warming has arguably been attributed to high latitude processes both in 108 the North Atlantic and the Southern Ocean. Based on the reanalysis of hydrographic data 109 collected since 1970 it has been argued that a large part of the recent increase in OHC, 110 particularly below $1000 \mathrm{~m}$, occurred in the Atlantic. Accordingly, the heat gain may be 111 due to the enhancement of the Atlantic Meriodional Overtruning Circulation (AMOC) in 112 response to the recurrent salinity anomaly in the subpolar North Atlantic (Balmaseda et 113 al., 2013; Chen and Tung, 2014). Accordingly, the recovery from the great salinity 114 anomaly of the mid $20^{\text {th }}$ century (Curry et al., 2003), led to the increase in surface 115 density, which would have enhanced vertical convection in the Labrador Sea and 116 subpolar region leading to greater sequestration of heat and $\mathrm{CO}_{2}$. This observational117 based hypothesis is consistent with model results suggesting that variations in the 
118 strength and depth of the AMOC plays a key role in transporting and redistributing

119 thermal energy to depth, thus regulating the heat capacity of the ocean in response to

120 climate change (Kostov et al., 2014) .

121 An alternative, though not a mutually exclusive explanation, attributes the global

122 increase in $\mathrm{OHC}$ at intermediate depths ( $700-1400 \mathrm{~m})$ to greater heat gain from surface

123 ocean-atmospheric interactions in the Southern Ocean (Roemmich et al., 2015;

124 Roemmich et al., 2007). The greater heat gain in the Southern Ocean could be partly

125 caused by the faster warming rate of the Southern vs. Northern Hemisphere high latitudes

126 and the greater area of the Southern Ocean. However, it has been proposed that the

127 strengthening of the Southern Westerly Winds (SWW) and resultant spin up of the

128 subtropical gyres, played a more important role in enhancing the heat gain in the southern

129 high latitudes. The strengthening and poleward shift of the SWW occurred in response to

130 a positive Southern Annular Mode since 1970 (Thompson et al., 2011). The poleward

131 shift of the SWW enhances the large-scale upwelling in the Southern Ocean due to

132 Ekman divergence south of the Polar Front $\left(\sim 50^{\circ} \mathrm{S}\right)$, thus bringing deep colder water to

133 the surface, which in turn promotes heat and gas uptake from the atmosphere.

134 Continuous upwelling and relatively quick northward transport of the cold waters at the

135 surface limits the surface warming in this region thereby sustaining efficient heat uptake

136 (Morrison et al., 2016; Russell et al., 2006). For example, in model simulations a

137 poleward intensification of the SWW results in substantially higher heat and $\mathrm{CO}_{2}$ uptake

138 in the Southern Ocean compared with a model run with a more equatorward position of

139 the SWW, suggesting that air-sea heat exchange in the Southern Ocean may be

140 dominated by dynamic processes (e.g., (Russell et al., 2006; Stouffer et al., 2006).

141 The brevity of the observational record makes it difficult to understand the relative 142 importance of the mechanisms controlling changes in $\mathrm{OHC}$ and the role of the ocean in

143 climate. This is because the properties of the deep, and to a lesser extent, intermediate

144 water masses reflect climate perturbations at the surface, which are integrated over

145 relatively long time scales due to the long residence time of these water masses and their

146 tendency to reach a steady state through mixing and diffusion. A longer perspective on

147 changes in $\mathrm{OHC}$, obtained from paleoceanographic proxy records helps to understand the

148 role of the different processes in climate change over various time scales (decades to 
149 millennia) and provides a baseline to evaluate the current instrumental observations.

150 Here we review currently available records of $\mathrm{Mg} / \mathrm{Ca}$-derived sea surface and

151 intermediate water temperatures (SST and IWT, respectively) through the Holocene,

152 Common Era and the recent decades, periods characterized by very different external

153 forcings. The records show substantial changes in intermediate ocean temperature and

154 inferred $\mathrm{OHC}$ during these time intervals. Because the changes in mean annual radiative

155 forcing were minimal, we hypothesize that changes in oceanic and atmospheric

156 dynamics, in response to small changes in radiative forcings, were the main control on

157 ocean heat exchange and $\mathrm{OHC}$ during the Holocene and Common Era.

159 Holocene trends in Sea Surface Temperatures

160 Insights into the change of $\mathrm{OHC}$ can be gained from comparing surface and

161 intermediate-water temperature records reconstructed from foraminifera in sediment

162 cores. (Marcott et al., 2013) present a global SST reconstruction for the Holocene based

163 on all the available proxy records at that time. The SST reconstruction shows the

164 Holocene Thermal Maximum (HTM) occurred during the early-to-mid Holocene (10,000

165 to 5000 years ago) followed by a $\sim 0.7^{\circ} \mathrm{C}$ cooling toward the Little Ice Age (LIA). The

166 HTM timing differs among sites but generally suggests $\sim 0.5^{\circ}$ warmer temperatures than

167 recorded at the core tops. The interpretation of this cooling trend as reflecting mean

168 annual global SST is, however, complicated by the apparently contradicting trends

169 recorded by alkenone and $\mathrm{Mg} / \mathrm{Ca}$ based records particularly in the tropics (Leduc et al.,

170 2010). While the cause of these offsets is investigated (e.g., Timmermann et al., 2014),

171 here we present a subset of the Marcott et al. (2013) data, based only on SST records

172 derived from $\mathrm{Mg} / \mathrm{Ca}$ measurements in the mixed-layer foraminifer Globogerinoides

173 ruber (s.s) (Fig. 2). This should minimize biases due to ecological and seasonal

174 preferences of the different proxy carriers (e.g., foraminiferal based $\mathrm{Mg} / \mathrm{Ca}$ and

175 haptophytes derived alkenones). We note, however, that the results from this subset of

176 records are consistent with the combined multi-proxy record of Marcott et al., (2013).

177 We present the data from low-latitude sites, compiled into three regions representing the

178 western Pacific warm pool (WPWP) (average of 8 sites), eastern Pacific (average of 3 
179 sites) and the equatorial Atlantic (average of 5 sites). All sites are far from the influence

180 of the polar ice sheets and oceanographic frontal regions and thus should be more

181 representative of the direct climate response to the Holocene radiative perturbations. For

182 consistency, we are using the same age models and temperatures reported in Marcott et

183 al., (2013).

$184 \mathrm{The} \mathrm{Mg} / \mathrm{Ca}$ reconstructions from all three regions suggest that SSTs during the HTM

185 were warmer by a few tenths of a degree relative to the late Holocene (Fig. 3a-c).

186 Considering the variability among the records, it can be concluded that in the low latitude

187 regions, the HTM and subsequent cooling trend toward the late Holocene was very small

$188\left(<0.5^{\circ} \mathrm{C}\right)$ consistent with the larger, multi-proxy, compilation (Marcott et al., 2013).

189 There are, however, small differences among regions. The WPWP shows about $0.5^{\circ} \mathrm{C}$

190 cooling trend from the early to late Holocene consistent with earlier studies (Linsley et

191 al., 2010; Stott et al., 2004). The observed SST cooling in the WPWP is apparently at

192 odds with the expected warming from the increase in atmospheric $\mathrm{pCO}_{2}$ through the

193 Holocene and the change in local insolation (Liu et al., 2003) ; (Liu et al., 2014). The

194 apparent discrepancy has been attributed to the possibility that foraminiferal $\mathrm{Mg} / \mathrm{Ca}$ may

195 be recording seasonal rather than mean annual temperatures (Timmermann et al., 2014).

196 We note, however, that records from both sides of the equator, experiencing opposing

197 insolation trends through the Holocene, show similar trends (Linsley et al., 2010), which

198 seems to suggest that seasonality may not exert the dominant control on the $\mathrm{Mg} / \mathrm{Ca}$-based

199 SST records in this region. In the eastern Pacific, reconstructed SST is relatively stable

200 until about $4 \mathrm{ka}$ followed by a $\sim 0.5^{\circ} \mathrm{C}$ cooling in the late Holocene. A similar trend is

201 observed in the equatorial Atlantic, with relatively stable SST from 12-5 ka followed by a

$202 \sim 0.5^{\circ} \mathrm{C}$ cooling from $\sim 4 \mathrm{ka}$ to the present. The late Holocene cooling in the eastern

203 equatorial Pacific, is likely due to the intensification of, coastal upwelling in response to

204 changing atmospheric circulation after 4 ka (Nürnberg et al., 2015), which probably

205 also explains the similar trend in paleo-records from the equatorial Atlantic. 
Reconstructing temperature changes of the ocean interior during the Holocene is more challenging due to the limited number of cores with sufficient resolution at 210 intermediate depths. To date, $\mathrm{Mg} / \mathrm{Ca}$ in benthic foraminifera is the only available proxy 211 for reconstructing deep sea temperatures (see review by (Katz et al., 2010). The low 212 temperature sensitivity of $\mathrm{Mg} / \mathrm{Ca}$ in benthic foraminifera species, typically used for 213 reconstructing Cenozoic and glacial-interglacial changes (e.g., Planulina wuellerstorfii,

214 Oridorsalis umbinatus and Uvigerina sp.),and other non-temperature related effects (e.g., 215 the effect of carbonate saturation), often limit their application for reconstructing small 216 changes in intermediate water temperatures. However, a recent calibration of Hyalinea

217 balthica, a shallow infaunal species abundant in neritic to upper bathyal and shelf 218 sediments, offers a more sensitive paleothermometer suitable for reconstructing IWT.

219 Core top calibrations suggest a temperature sensitivity of $\sim 12 \%$ per ${ }^{\circ} \mathrm{C}$, which is about 220 four times higher than observed in deep sea benthic foraminifera (Rosenthal et al., 2011).

221 The challenge is, however, to find sites that intersect the major oceanic water masses, 222 have high accumulation rates and contain this foraminifera species.

223 Over the past several years we have generated several intermediate depth records 224 from three key locations in the western and eastern equatorial Pacific (Fig. 3d-f) and 225 northeastern subtropical Atlantic (Fig. 3g). We discuss additional IWT reconstructions 226 from the North Atlantic and North Pacific, however these are, based on $\mathrm{Mg} / \mathrm{Ca}$ records 227 from the benthic species Hoeglunandina elegans (Came et al., 2007) and $C$. 228 wuellerstorfi (Kubota et al., 2015), which have much lower temperature sensitivity 229 relative to $H$. balthica and thus should be treated cautiously. The intermediate water 230 records at all three regions suggest $2 \pm 0.5^{\circ} \mathrm{C}$ warmer temperatures during the early 231 Holocene relative to the pre-industrial late Holocene. The pattern of the HTM and 232 subsequent cooling of IWT toward the modern is different than, and exceeds the 233 magnitude seen at the overlying surface. These differences suggest that the long-term 234 Holocene trends in IWT are not directly driven by changes in local radiative forcing but 235 more likely are sourced from the high latitude and transported as heat anomalies to the 236 ocean's interior.

237 A closer examination of the changes in each region helps to understand the sources 238 and mechanisms behind the reconstructed changes. The western equatorial Pacific 
239 records are based on $\mathrm{Mg} / \mathrm{Ca}$ measurements of the benthic foraminifera $H$. balthica from

240 four cores constituting a bathymetric transect ( $500-900 \mathrm{~m}$ water depth) in the Makassar

241 Strait and Flores Sea in Indonesia (Rosenthal et al., 2013). This region is well suited to

242 reconstruct mean western Pacific $\mathrm{OHC}$, as thermocline and intermediate water masses

243 found there form in the mid- and high-latitudes of both the northern and southern Pacific

244 Ocean. These water masses can be traced by their distinctive salinity and density as they

245 flow towards the equator (Fine et al., 1994; Gordon, 2005; Rosenthal et al., 2013). Here,

246 the modern thermocline ( $200-500 \mathrm{~m})$ is dominated by North Pacific Intermediate Water

247 (NPIW) contributing to the Indonesian Throughflow (ITF), which flows into the Indian

248 Ocean. The relatively uniform water mass below the main thermocline $(450-1000 \mathrm{~m})$

249 known as Indonesian Intermediate Water forms in the Banda Sea via strong vertical

250 mixing between shallow/warm/relatively fresh and deep/cold/relatively salty waters

251 (Gordon, 2005; Talley and Sprintall, 2005). At intermediate depths, the northwestward

252 flowing New Guinea Coastal Undercurrent, which originates in the South Pacific, flows

253 through the Indonesian passages and reaches the Banda Sea, carrying a significant

254 contribution of Antarctic Intermediate Water (AAIW) (Zenk and et al., 2005). The IWT

255 records from the Makassar Strait show cooling trends from the early-mid to the late

256 Holocene of about $2.2 \pm 0.4$ at $500 \mathrm{~m}$ and $1.5 \pm 0.3^{\circ} \mathrm{C}$ at $600-900 \mathrm{~m}$ (Rosenthal et al., 2013).

257 Based on the modern hydrography and given the similarity of the records at all depths,

258 we have argued that Holocene IWT changes in the western equatorial Pacific are linked

259 to climate variability in both the northern and southern high latitudes (Rosenthal et al.,

260 2013). However, because of the vigorous deep mixing in the Banda Sea, a link to either

261 of the hemispheres could not unequivocally be established.

262 Water at the base of the eastern equatorial Pacific (EEP) thermocline, known as the 263 thermostad ( 150-350 $\mathrm{m}$ water depth) or $13^{\circ} \mathrm{C}$ Mode Water (Tsuchiya, 1981) is linked to

264 the Southern Ocean through the influence of Subantarctic Mode Water (SAMW)

265 (Kalansky et al., 2015); and references therein). A Mg/Ca record of deep dwelling

266 planktonic foraminifer (Neogloboquadrina dutertrei with an estimated depth habitat of

$267 \sim 120 \mathrm{~m}$ below surface in the EEP region) from a core situated at $375 \mathrm{~m}$ water depth on

268 the Peru Margin suggests higher temperatures during the early Holocene and a sharp

269 cooling of $\sim 2^{\circ}$ by $\sim 8 \mathrm{ka}$ (Kalansky et al., 2015). After a relatively stable period between 
$270 \sim 7$ and $4 \mathrm{ka}$, there is an additional $\sim 1^{\circ} \mathrm{C}$ cooling to the present (Fig. 3e). The strong

271 covariance with the bottom temperature reconstruction from the benthic foraminifer

272 Uvigerina spp. in this core suggests that the planktonic record primarily represents

273 changes in thermocline temperature/depth likely linked to climate change in the Southern

274 Ocean (Kalansky et al., 2015). Antarctic ice cores (Masson-Delmotte et al., 2011;

275 Mulvaney et al., 2012), terrestrial records (Verleyen et al., 2011) and Southern Ocean

276 temperature reconstructions (Shevenell et al., 2011) show warming associated with the

277 Younger Dryas and a near synchronous early HTM ( 11.5-9 Ka) followed by a sharp

278 cooling by $\sim 8 \mathrm{ka}$. Based on the similarity with these records, it has been argued that the

279 early Holocene temperature change in the thermostad originated in the southern high

280 latitudes and was advected to the EEP thermostad by SAMW (Kalansky et al., 2015).

281 Foraminiferal $\delta^{13} \mathrm{C}$ and $\varepsilon \mathrm{Nd}$ records from the eastern equatorial Pacific support the

282 greater influence of Southern Ocean water on the thermostad during the late deglaciation

283 and early Holocene (Pena et al., 2008; Pena et al., 2013; Spero and Lea, 2002).

284 Elevated thermostad temperatures during the early Holocene have been linked to 285 regional changes in climate conditions in the Southern Ocean (Kalansky et al., 2015).

286 Particularly a more southward position of the SWW during the early Holocene enhanced 287 the contribution of warm subtropical water to the forming SAMW and the eastern 288 equatorial Pacific thermostad (Bostock et al., 2013) (Bova et al., 2015). Based on opal 289 accumulation records from cores in the South Atlantic and SW Pacific it has been argued 290 that the SWW shifted southward after the Antarctic Cold Reversal ( $13 \mathrm{Ka}$; (Anderson 291 et al., 2009), and likely remained in a more poleward position until around 9-8 ka. This 292 hypothesis is supported by different lines of paleoceanographic evidence including 293 temperature records from Antarctic ice cores (e.g.,(Masson-Delmotte et al., 2011;

294 Mulvaney et al., 2012), reconstructions of Antarctic and Subantarctic SST (Bianchi and

295 Gersonde, 2004; Kaiser et al., 2005; Pahnke and Sachs, 2006; Pahnke and Zahn, 2005;

296 Shevenell et al., 2011) and sedimentary evidence for shifts in the precipitations belt in

297 southern America (Bender et al., 2013; Lamy et al., 2010) (Fig. 4).

298 Models show that AAIW production is strongly related to the location and strength of 299 the SWW. Thus the effect of the SWW is not limited to the Subtropical Front (e.g., 
300 (Russell et al., 2006; Stouffer et al., 2006). A poleward shift of the SWW and associated

301 polar front during the deglaciation and early Holocene likely led to increased upwelling

302 of relatively warm upper circum polar deep water (UCDW) around Antarctica (Peck et

303 al., 2015; Toggweiler et al., 2006). While flowing northward, the upwelled UCDW was

304 further warmed by heat exchange with the atmosphere before mixing into the newly

305 formed AAIW and SAMW, which contributed to the early Holocene OHC maximum. A

306 northward migration of the SWW and associated polar fronts reduced the contributions of

307 both subtropical surface water and upwelled UCDW to SAMW formation regions

308 thereby leading to progressive cooling of the intermediate water masses originating from

309 the Southern Hemisphere. Migrations of the SWW have been attributed to changes in the

310 Hadley circulation in response to a change in the latitudinal temperature gradient (LTG)

311 (Chiang and Friedman, 2012). On orbital time scales the main mechanism that regulates

312 the latitudinal distribution of insolation and thus the LTG is the interplay between the 41

313 ka obliquity cycle and the 21 ka precession cycle, which varied significantly throughout 314 the Holocene.

315 The patterns and timing of these changes were, however, not uniform around the

316 Antarctic region with some sectors showing an early HTM and subsequent cooling to

317 almost modern temperatures by $8 \mathrm{Ka}$, whereas other regions follow a more Northern

318 Hemisphere pattern with gradual cooling starting at $\sim 7 \mathrm{Ka}$ as recorded for example in

319 Taylor Dome, Antarctica (e.g., (Masson et al., 2000; Steig et al., 2000) and sediment

320 records (e.g., (Anderson et al., 2009; Hodell et al., 2001; Peck et al., 2015; Shevenell et

321 al., 2011). Thus the signals recorded in intermediate water masses were likely affected

322 by climate variability at the different formation sites, which may explain the differences

323 among our records. As we have no records below $350 \mathrm{~m}$ from the EEP, we cannot say

324 whether intermediate water masses in this region experienced comparable changes to the

325 EEP thermostad or to those observed at intermediate depths in the Indonesian cores.

326 At present the dominant water mass within the lower thermocline of the Makassar

327 Strait ( 200-500m) is the low salinity NPIW (Gordon, 2005). Therefore, Rosenthal et al.

328 (2013) suggested that the shallowest records from the Makassar Strait ( 500-600 m)

329 might reflect changes in the properties of the NPIW. NPIW currently forms during the

330 winter by brine rejection and sinking of dense shelf water in the Sea of Okhotsk (Talley, 
331 1991). In contrast with the southern hemisphere, the winter/spring insolation minimum

332 occurred during the early Holocene at high northern latitudes, increasing monotonically

333 towards the present. Alkenone derived SST records show higher SST during the early

334 Holocene in several parts of the Okhotsk Sea and NW Pacific followed by a cooling

335 towards the late Holocene (Harada et al., 2014; Max et al., 2014). This trend is

336 interpreted to reflect warmer late summer/autumn temperatures consistent with the higher

337 summer/autumn insolation at that time. The concurrent reduction in sea ice extent in the

338 Okhotsk Sea have led these authors to argue for a reduction of NPIW production during

339 the early Holocene. A low-resolution $\mathrm{Mg} / \mathrm{Ca}$ record generated from the benthic

340 foraminifer $C$. wuellerstorfi extracted from a core on the continental slope east of

341 Okinawa Island (1166 m water depth) may provide insight on the Holocene history of

342 NPIW. The low-resolution record shows no discernible trend through the Holocene

343 (Kubota et al., 2015)S suggesting that the observed changes in the Makassar sites might

344 not be related to changes in the formation of NPIW. A similar interpretation is drawn

345 from a benthic foraminifera record of mid-water depth radiocarbon content in the

346 northwest Pacific Ocean indicating that NPIW ventilation was stronger in the early ( 9-6

$347 \mathrm{Ka})$ than the late Holocene $(\sim 2.5-1.5 \mathrm{Ka})$, apparently in contrast with the interpretations

348 of sea surface conditions in the Okhotsk Sea and northwest Pacific (Max et al., 2014;

349 Rella and Uchida, 2014). The decoupling between the radiocarbon derived changes in

350 NPIW ventilation, and surface conditions in the northern Pacific led the authors to

351 suggest that at intermediate depths, the NW Pacific might have responded to changes in

352 the Southern Ocean overturning forced by latitudinal displacements of the SWW (Rella

353 and Uchida, 2014). Accordingly, enhanced ventilation of NPIW during the early

354 Holocene, observed in a core off Japan, is due to a stronger contribution of AAIW to the

355 NW Pacific and enhanced mixing with the overlying NPIW. If these interpretations are

356 correct, temperature changes observed in our Indonesian cores within the lower

357 thermocline might have also been sourced from the Southern Hemisphere due to wind

358 induced convective processes associated with the Southerly Jet.

360 Holocene Changes in Atlantic OHC 
361 Recent changes in North Atlantic intermediate and deepwater temperatures are

362 possibly related to variations in the AMOC in response to recent anomalies in the sub

363 polar gyre (SPG) surface salinities (Balmaseda et al., 2013; Chen and Tung, 2014).

364 Temperature reconstruction, based on a $\mathrm{Mg} / \mathrm{Ca}$ record from the benthic species

365 Hoeglunandina elegans from a sediment core on the flanks of the Little Bahama Bank

$366(\mathrm{LBB})$ at $1,057 \mathrm{~m}$ water depth suggests that IWT was $>2^{\circ} \mathrm{C}$ warmer during the early

367 Holocene than today (Fig. 3). The $\sim 1.5^{\circ} \mathrm{C}$ cooling after 8 ka.is likely due to the cooling

368 of high latitude North Atlantic surface waters, where this intermediate water mass is

369 formed (Came et al., 2007). A higher resolution $H$. balthica $\mathrm{Mg} / \mathrm{Ca}$ record from $\sim 900$

$370 \mathrm{~m}$ water depth in the northeastern subtropical Atlantic shows a further $\sim 1^{\circ} \mathrm{C}$ cooling at $~$

$3713.5 \mathrm{ka}$ in response to climate variability at the North Atlantic high-latitudes (Morley et

372 al., 2011). The core, situated in the northeastern part of the Atlantic on the African

373 margin, is under the influence of Eastern North Atlantic Central Waters (ENACW), an

374 intermediate water mass that largely consists of Subpolar Mode Water (SPMW) and

375 therefore is highly susceptible to ocean-atmosphere interactions in the region of the SPG.

376 Morley et al. (2011) showed that past temperatures and salinity of ENACW recorded off

377 the Northwest African continental margin are determined by SPMW formation south and

378 west of Iceland on both instrumental, multidecadal and multicentennial timescales

379 throughout the Holocene (Bamberg et al., 2010; Morley et al., 2014; Morley et al., 2011).

380 Essentially, ENACW circulation provides an 'oceanic tunnel' (Liu and Alexander,

381 2007) transmitting subpolar ocean-atmospheric climate anomalies to lower latitudes and

382 the oceans interior. SPMW properties (temperature and salinity) in turn depend on (1) the

383 strength of the northern mid-latitude westerlies during the winter, (2) SPG surface ocean

384 dynamics and (3) the freshwater input of East Greenland Current (EGC) waters into the

385 SPMW formation region.

386 Over the HTM-to-Late Holocene transition the $\mathrm{Mg} / \mathrm{Ca}$ based intermediate water 387 temperature record shows a distinct $\sim 1^{\circ} \mathrm{C}$ cooling of ENACW between 3.3 and 2.6 ka.

388 (Fig. 2g). This shift in ENACW hydrography is attributed to 1) high latitude sea surface

389 cooling and increased winter sea ice extent in the Barents Sea, 2) a southeastward

390 advance of the Sub Arctic Front (SAF) south of the Denmark Strait linked to a stronger

391 influence of the EGC in the Irminger and Iceland Seas; and 3) as a result of (2) cooler and 
392 fresher SPMW. These changes have been linked to changes in the latitudinal insolation

393 gradient during the Holocene in response to the Holocene changes in northern

394 hemisphere insolation (Morley et al., 2014). The main mechanism that regulates the

395 latitudinal distribution of insolation is the interplay between the 41 kyr obliquity cycle

396 and the 21 ka precession cycle. Both model analysis and proxy data show that high-

397 latitude peak summer insolation and low-latitude minimum winter insolation resulted in

398 reduced latitudinal temperature gradient due to warming in the Arctic (Davis and

399 Brewer, 2008) and cooling in the tropics during the HTM (Bonfils et al., 2004; Davis

400 and Brewer, 2008). The resultant changes in latitudinal temperature gradient over the

401 mid-to late Holocene transition set in motion a chain of positive climate feedback

402 affecting the air-sea heat exchange processes leading to the observed change in ENACW

403 temperature and heat content (Morley et al., 2014).

404 Weaker latitudinal insolation gradients during the HTM are also likely to have altered 405 atmospheric circulation regimes, especially over the northern mid-latitudes. Modern

406 observations show that weaker latitudinal temperature and air thickness gradients

407 between the poles and the tropics decrease the speed and elongate the wave amplitude of

408 the polar Jet stream resulting in slower moving circulatory systems. The resultant

409 prolonged weather conditions are now referred to as 'atmospheric blocking' (Francis

410 and Vavrus, 2012). Häkkinen et al. (2011) propose that 'atmospheric blocking' over the

411 subpolar North Atlantic also fundamentally influences ocean circulation and upper ocean

412 air-sea exchange. This is because a more southeasterly position of the mid-latitude

413 Westerlies (Woollings et al., 2008) and weaker storm intensities during weaker LTG

414 lead to a reduction in heat loss over the subpolar North Atlantic which in turn result in a

415 weaker SPG circulation. A weaker SPG circulation is characterized by a North-South

416 oriented gyre that allows warmer and more saline water of subtropical origins to enter the

417 Nordic Seas through the Rockall Trough further weakening the gyre (Hátún et al.,

418 2005). In summary, we suggest that changes in LTG over the mid-to late Holocene

419 transition set in motion a chain of dynamic feedback processes that resulted in the

420 observed response of the North Atlantic OHC (Morley et al., 2014).

421 


\section{The Common Era}

423 Superimposed on the Holocene trends is significant multi-centennial variability

424 expressed both at the surface and intermediate depths. Northern hemisphere surface

425 temperature reconstructions for the Common Era show $0.8 \pm 0.3^{\circ} \mathrm{C}$ cooling from the

426 Medieval Climate Anomaly (MCA, between 950 and $1250 \mathrm{CE}$ ) to the LIA (between 1550

427 and $1850 \mathrm{CE}$ ) (Mann and et al., 2008). In the past 150 years, the NH surface temperature

428 returned to the MCA levels and is likely as warm or warmer than any other time during

429 the last 1,300 years (Mann et al., 2008; Moberg and et al., 2005). The SST reconstruction

430 from the WPWP, the largest warm water region on the planet, closely follows the

431 Northern Hemisphere temperature reconstruction (Oppo et al., 2009), demonstrating a

432 strong coherence between climate variability in the WPWP and the Northern Hemisphere

433 high latitudes (Fig 5a). Reconstructions of IWT from Indonesia, spanning depths of $\sim 500$

434 to $900 \mathrm{~m}$, share strong similarity with surface temperatures except at the last two

435 centuries. Pacific IWT were $0.9 \pm 0.3^{\circ} \mathrm{C}(1 \mathrm{SEE})$ colder during the LIA than during the

436 MCA. Within age model errors, the IWT cooling from the MCA to LIA is of the same

437 magnitude as (and possibly lags) the cooling of the overlying surface water and the

438 cooling recorded in the Northern Hemisphere. Lowest temperatures occur during the 17 -

$43918^{\text {th }}$ centuries both at the surface and intermediate depths. Subsequently the SST and

440 IWT records diverge. Surface temperatures warmed by $\sim 0.5 \pm 0.15^{\circ} \mathrm{C}$ for the period of

441 1850-1950 CE, which is remarkably consistent with the instrumental record for the same

442 period returning to MCA levels. In a sharp contrast, modern IWT in Indonesia are about

443 the same as during the LIA (Fig. 5b). The slow recovery of the IWT is not surprising

444 given that in this equatorial site it takes many decades for the intermediate water masses

445 to reach the western equatorial Pacific from their high-latitude origin (Fine et al., 1994).

446 This large lag between the Indonesian IWT records and the changes recorded at the

447 surface suggest that large parts of the ocean interior are not in equilibrium with the recent

448 climate change. A closer link and relatively rapid response between surface

449 ocean/atmosphere conditions and downstream intermediate water temperatures can be

450 seen in the northeastern Atlantic site, situated closer to the possible source region. The

4511200 year long benthic foraminiferal $\mathrm{Mg} / \mathrm{Ca}$ from the $\sim 900 \mathrm{~m}$ deep site off northwest 
452 Africa discussed above shows strong centennial scale temperature variability on the order 453 of $0.7^{\circ} \mathrm{C}$ superimposed on a gradual cooling of $\sim 1^{\circ} \mathrm{C}$ from 950 to $1850 \mathrm{CE}$.

454 The causes of the last millennium climate anomalies are debated. At present it is

455 thought that the LIA cooling was caused by the combined effects of changes in total solar 456 irradiance (TSI) and explosive volcanic activity (e.g., (Crowley, (2000a)). Recent model 457 simulations estimate the direct radiative perturbations during the last millennium to be 458 about $-0.2 \pm 0.1 \mathrm{~W} / \mathrm{m}^{2}$ (e.g., (Schmidt et al., 2012) largely due to enhanced explosive 459 volcanism during the LIA and to a lesser extent changes in TSI (Atwood et al., 2016).

460 Models using these forcings, simulate the general climate anomalies of the last 461 millennium as recorded by various proxy reconstructions (Atwood et al., 2016; Landrum 462 et al., 2013). The simulations suggest, however, that the combination of all the direct 463 forcings contribute to only about half of the cooling during the LIA, whereas the rest is 464 driven by positive feedbacks (Atwood et al., 2016).

465 Simulations of the temperature variability during the last millennium are generally 466 consistent with proxy compilations, suggesting $\sim 0.3^{\circ} \mathrm{C}$ global cooling from the MCA to 467 LIA (Atwood et al., 2016; Landrum et al., 2013). Although these anomalies are smaller 468 than suggested from proxy records of surface and subsurface temperatures, the 469 simulations suggest a factor of two or larger anomalies in the polar regions, especially 470 during the cold seasons of intermediate and deep water formation (e.g., (Landrum et al., 471 2013). The implied strengthening in the LTG, and associated expansion of sea ice 472 coverage from the MCA to LIA suggested by the models, could have led to major 473 changes in the atmospheric and oceanographic conditions in the polar regions and are 474 likely the cause of the LIA cooling and decrease in heat content of the eastern North 475 Atlantic central water (Morley et al., 2011). The importance of dynamic processes and 476 feedbacks relative to changes in the background forcing is reflected in the $\sim 0.5^{\circ} \mathrm{C}$ cooling 477 of ENACW during the past 150 years. This cooling trend, which seems at first at odds 478 with global warming of $\sim 0.9^{\circ} \mathrm{C}$ due to the increase in $\mathrm{GHG}$, is likely related to enhanced 479 sea surface heat loss due to stronger Mid-latitude Westerly Winds over the northeastern 480 SPG since the early $19^{\text {th }}$ century (Morley et al., 2011). This recent cooling trend is also 481 present in SST proxy reconstructions (Hall et al., 2010) and in instrumental SST datasets 482 from the northeastern SPG (Xue et al., 2003) demonstrating the intimate link between 
483 surface conditions in the high latitudes and intermediate water $\mathrm{OHC}$ in the North 484 Atlantic.

485 While it is difficult to link changes in IWT recorded in Indonesian cores to their 486 source regions, we assume that similar dynamic mechanisms that were responsible for the 487 Holocene trends also contributed to the last millennium anomalies in intermediate water 488 OHC despite the difference in the forcings. In the Southern Ocean, the enhanced cooling 489 and extended sea ice coverage during the LIA, suggested in model simulations (e.g., 490 (Landrum et al., 2013), possibly also resulted in a shift in the SWW. Indeed there are 491 indications of significant cooling during the LIA and possible changes in wind strength 492 and/or position during the LIA (Abram et al., 2013; Chambers et al., 2014; Orsi et al., 493 2012; Rhodes et al., 2012). These processes could have led to a negative heat anomaly in 494 the formation sites of Antarctic intermediate and mode waters, which could have affected 495 the intermediate water temperatures in the western equatorial Pacific (Rosenthal et al., 496 2013).

497 Although the background radiative anomaly throughout the last millennium was very 498 small, significantly larger negative anomalies likely followed major/successive volcanic 499 eruptions resulting in multi decadal cooling on the order of $1-1.5^{\circ} \mathrm{C}$ (Atwood et al., 2016; 500 Landrum et al., 2013). Models simulating the effects of major volcanic eruptions suggest 501 increased air-sea heat exchange at the southern high latitudes resulting in persistent 502 negative $\mathrm{OHC}$ anomalies in subsurface water masses (e.g., (Gleckler et al., 2006;

503 Stenchikov et al., 2009). Another simulated consequence of volcanic eruptions is the 504 expansion of sea ice coverage in the Arctic and Nordic Seas that can lead to changes in 505 the AMOC although the exact response differs among models (e.g., (Ding et al., 2014;

506 Schleussner and Feulner, 2013). Records of sea ice extent and ice caps growth from 507 Arctic Canada and Iceland (Miller et al., 2012) suggest that the LIA was a result of large 508 explosive volcanism causing cooling and expansion of the sea-ice. This hypothesis is 509 supported by transient modeling suggesting that explosive volcanism can result in 510 Northern Hemisphere summer cooling and expansion of sea-ice, which may persist long 511 after the eruption due to sea-ice/ocean feedbacks, which might contributed to the LIA 512 cooling (Miller et al., 2012). Regardless of the exact mechanism, the models suggest that 513 the negative radiative forcings from an eruption, penetrates to the subsurface within a few 
514 years after the eruption but the anomaly persists much longer with slow relaxation

515 persisting for decades and centuries in the mid-depth and deep ocean, respectively (Ding

516 et al., 2014; Stenchikov et al., 2009). We suggest that in addition to the direct negative

517 radiative forcing caused by successive volcanic eruptions (Consortium, 2013), the

518 persistent upwelling of progressively previous negative heat anomalies to the surface

519 contributed to the cooling during the LIA. A similar mechanism has been proposed as a

520 mediating process for the recent global warming (Gleckler et al., 2006; Rosenthal et al.,

521 2013).

522

\section{The Recent Two Centuries}

524 As discussed above, decadal changes in surface conditions in the tropical and

525 subtropical Pacific appear to be one mechanism for regulating upper $\mathrm{OHC}$ on decadal

526 time-scales (e.g.; England et al., 2014; Meehl et al., 2013; Trenberth and Fasullo, 2013).

527 (Linsley et al., 2015) reported evidence of a positive correlation between decadal changes

528 in South Pacific upper OHC and reconstructed subtropical South Pacific SST from a

529 composite of coral core $\mathrm{Sr} / \mathrm{Ca}$ records from Fiji, Tonga and Rarotonga (FTR). Over the

530 interval of overlap with Levitus et al. (2012) back to 1950, during decades of elevated

531 South Pacific SST, upper ocean heat content in the South Pacific rises. FTR coral $\mathrm{Sr} / \mathrm{Ca}$

532 SST and instrumental SST are also inversely correlated with decadal changes in

533 equatorial Pacific coral Sr/Ca SST (see Linsley et al., 2015). In Figure 6 we compare the

534 FTR composite coral $\mathrm{Sr} / \mathrm{Ca} \mathrm{SST}$ record to $0-700 \mathrm{~m}$ upper $\mathrm{OHC}$ for the S. Pacific and to an

535 equatorial composite coral $\delta^{18} \mathrm{O}$ record generated by averaging results from Fanning

536 Atoll (Cobb et al., 2013), Palmyra (Cobb et al., 2013) and Maiana (Urban et al., 2000)

537 (FPM index, defined in Linsley et al., 2015). Although coral $\delta^{18} \mathrm{O}$ can be sensitive to

538 changes in both water temperature and salinity, this comparison suggests that decadal-

539 scale changes in FPM coral $\delta^{18} \mathrm{O}$ are in part driven by changes in SST and demonstrates

540 the opposite response of the equatorial and subtropical South Pacific on decadal time-

541 scales. Collectively, these results and those presented in Linsley et al. (2015), in

542 combination with other conclusions drawn from paleo and instrumental data analysis

543 (e.g., (England et al., 2014; Thompson et al., 2015), indicate that over the past century, 
544 decades of stronger trade winds during negative phases of the PDO resulted in elevated

545 equatorial upwelling rates and generally cooler SST near the equator. Based on data from

546 primarily the late $20^{\text {th }}$ century, England et al. (2014) proposed the link between increased

547 trade winds, cool equatorial SSTs, intensified wind stress curl on either side of the

548 equator and a spin up of the subtropical gyres to explain both the increase in subduction

549 of warm subtropical water into the ventilated thermocline and the increase in subsurface

550 heat uptake in the western equatorial Pacific. The equatorial and South Pacific coral

551 results are completely consistent with this hypothesis. The 206 year long (1997-1791)

552 FTR coral $\mathrm{Sr} / \mathrm{Ca}$ reconstruction of Linsley et al. (2015) also indicates persistent decadal

553 SST variability back to 1791 with a mean recurrence interval of approximately 25 years.

554 This multi-century coral-based record thus supports the hypothesis that semi-periodic

555 decadal-scale changes in equatorial and subtropical Pacific surface ocean-atmosphere

556 conditions are involved in regulating heat storage in the upper ocean.

\section{Causes and implications of Holocene OHC change}

559 Temperature reconstructions presented here suggest that the HTM warmth and

560 subsequent cooling of intermediate water masses were not likely restricted only to the

561 western equatorial Pacific as previously documented (Rosenthal et al. 2013). Although,

562 the available record from the North Pacific apparently shows no significant cooling

563 through the Holocene (Kubota et al., 2015), records of intermediate waters from the

564 North Atlantic provide evidence for Holocene cooling, consistent with the records from

565 Indonesia. Likewise, the reconstructed IWT changes from the MCA to the LIA seem to

566 have affected intermediate water masses in both the Pacific and Atlantic Oceans. Both the

567 long-term trend cooling throughout the Holocene and the anomalies during the Common

568 Era i.e., the transition from the warm MCA to the cold LIA provide interesting case-

569 studies of changes in $\mathrm{OHC}$ under different natural conditions that can be compared with

570 the anthropogenically-driven changes over the past several decades. This is because the

571 external forcings during each of these periods were very different. The largest external

572 forcing throughout the Holocene was due to precessionally-driven changes in seasonal

573 insolation, which is anti-phased between the hemispheres. However, the apparent 
574 coherency among records influenced by water masses originating both in the northern

575 and southern hemisphere suggests that the observed trends in IWT cannot be directly

576 driven by insolation. While obliquity has symmetric effect on both hemispheres the total

577 change in mean annual insolation from the early to late Holocene was $<<1 \mathrm{~W} / \mathrm{m}^{2}$ at the

578 latitudes where these intermediate water masses form $\left(45-55^{\circ}\right)$. As discussed above, the

579 interaction between precession and obliquity not only changed local insolation but also

580 latitudinal temperature gradients, which strongly affect the prevailing atmospheric

581 systems and hence air-sea heat exchange. These dynamic processes provide an efficient

582 mechanism to amplify the small changes in orbital forcing, into relative large changes in 583 OHC.

584 Orbitally-driven changes in insolation were minimal during the last millennium and 585 cannot explain the changes in the Common Era. Instead, the MCA to LIA cooling is 586 attributed to the effects of volcanic eruptions and variations in total incoming insolation 587 (TSI) causing a negative radiative forcing on the order of $-0.2 \pm 0.1 \mathrm{~W} / \mathrm{m}^{2}$. It is generally 588 assumed that the effects of direct forcing through the last millennium were relatively 589 uniform in both hemispheres, much like the effects of the recent increase in GHG though 590 with substantially smaller impact compared with the estimated total anthropogenic 591 radiative forcing of $+1.6 \pm 0.8 \mathrm{~W} / \mathrm{m}^{2}$ (Forster and Ramaswamy, 2007).

592 Recent model simulations using Flexible-Ocean-Atmosphere-Land model suggests 593 that the changes in insolation during the HTM could have led to significant changes in 594 ocean heat uptake, especially due to the strong warming in the Southern Ocean high 595 latitudes (Luan et al., 2016). Although the magnitude of the simulated warming is 596 significantly smaller than recorded in our cores and it is restricted to depths greater than $5971000 \mathrm{~m}$, the results generally support our argument that warming of the intermediate 598 depths in the equatorial Pacific probably originated in the Southern Ocean much as is the 599 case at present. The MCA simulation shows a more uniform warming of the ocean 600 interior at all depths and indicates heat uptake both in the northern and southern 601 hemispheres. It is possible that the difference between the model results and the paleo602 data is because the models do not accurately mimic the dynamic, likely wind-driven, 603 processes that exert large control on the ocean-atmosphere heat exchange, especially in 604 the high latitudes. To better quantify these processes we'll need not only to "fine tune" 
605 the models but also to increase the distribution of the paleo-records to capture the full 606 depth and geographical extent of the changes. This is important because evidently small 607 differences in the heat exchange rate can lead to very large changes in OHC.

608 Based on the IWT records from the Indonesian region, Rosenthal et al. (2013) 609 suggested that Pacific OHC was likely much higher during the HTM than in the late 610 Holocene, and during the MCA than the LIA. Although the timing of the HTM and 611 subsequent cooling is not synchronous among sites, likely reflecting variable climate 612 conditions at the different source regions of these water masses, the available records 613 suggest that estimates of OHC provided by Rosenthal et al. (2013) (Fig. 7) are probably 614 conservative. Likewise, the reconstructed IWT changes from the MCA to the LIA likely 615 affected intermediate water masses in both the Pacific and Atlantic Oceans. Levitus et 616 al., (2012) report a mean volume warming of the $0-700 \mathrm{~m}$ ocean layer of $0.18^{\circ} \mathrm{C}$ between 6171955 and 2010 , corresponding to $+0.033^{\circ} \mathrm{C}$ per decade. To obtain a first order 618 comparison, we assume that our records represent the World Ocean and thus are 619 comparable in volume with the current estimates (Levitus et al., 2012). Assuming the 620 intermediate depth ocean $(0-700 \mathrm{~m})$ cooled between 10 and $2 \mathrm{Ka}$ by $\sim 1.5^{\circ} \mathrm{C}$ we calculate a 621 cooling rate $-0.002^{\circ} \mathrm{C}$ per decade. Similarly, considering the intermediate depth ocean $622(0-700 \mathrm{~m})$ cooled by $\sim 0.5^{\circ} \mathrm{C}$ between 1200 and $1600 \mathrm{CE}$ we calculate a temperature 623 change of $-0.013^{\circ} \mathrm{C}$ per decade. In both cases these rates are smaller than the modern 624 rates even when applying the observed IWT changes to the whole ocean (as opposed to 625 just the Pacific as was done in Rosenthal et al., (2103). These crude estimates 626 demonstrate that small but persistent perturbations in the earth energy budget can result 627 in large anomalies in IWT and consequently OHC. Put it differently, a warming rate of $628+0.004^{\circ} \mathrm{C}$ per decade over the last deglaciation $(\sim 20-10 \mathrm{Ka})$ would have caused an ocean 629 warming by $\sim 4^{\circ} \mathrm{C}$. These estimates further underscore the argument made by Rosenthal 630 et al., (2013) that over a long time the ocean's interior acts like a capacitor and builds up 631 large (positive and negative) heat anomalies that can mitigate or amplify global 632 temperature change as seen in the Holocene trend and Common Era anomalies, 633 respectively. Evidently the deep ocean is more sensitive to small external forcings than 634 the global surface ocean because of the high sensitivity of heat exchange in the high635 latitudes to climate variations. However, the redistribution of the heat in the ocean 
636 interior can affect ocean circulation and consequently air-sea heat exchange. The paleo-

637 record suggests that the nature of this feedback process (positive or negative) may change

638 but model simulations are required to explore this. It is therefore important to realize that

639 much as was the case for ocean acidification, warming of the ocean interior may have

640 unappreciated consequences for future climate and marine life (Laffoley and Baxter,

641 2016).

642

\section{Acknowledgements}

644 We would like to acknowledge Paula Moffa-Sanchez for commenting on the 645 manuscript. Y.R. thanks Isabel Hong for help with Adobe Illustrator. Research

646 discussed in this review article was supported by NSF funding (OCE1045377\&1003400)

647

\section{REFERNCES}

649 Abram, N.J., Mulvaney, R., Wolff, E.W., Triest, J., Kipfstuhl, S., Trusel, L.D., Vimeux, 

INTIMATE project). Quaternary Science Reviews 74, 35-57.

Bova, S.C., Herbert, T., Rosenthal, Y., Kalansky, J., Altabet, M., Chazen, C., Mojarro, A., Zech, J., 2015. Links between eastern equatorial Pacific stratification and atmospheric $\mathrm{CO} 2$ rise during the last deglaciation. Paleoceanography 30, 1407-1424.

Came, R.E., Curry, W.B., Oppo, D.W., Broccoli, A.J., Stouffer, R.J., Lynch-Stieglitz, J., 2007. North Atlantic Intermediate Depth Variability During the Younger Dryas: Evidence From Benthic Foraminiferal $\mathrm{Mg} / \mathrm{Ca}$ and the GFDL R30 Coupled Climate Model, Geophysical Monograph Series 173. American Geophys. Union.

Chambers, F.M., Brain, S.A., Mauquoy, D., McCarroll, J., Daley, T., 2014. The 'Little Ice Age' in the Southern Hemisphere in the context of the last 3000 years: Peat-based proxy-climate data from Tierra del Fuego. The Holocene, 1-8. DOI: $10.1177 / 0959683614551232$

Chen, X., Tung, K.-K., 2014. Varying planetary heat sink led to global-warming slowdown and acceleration. Science 345, 897-903.

Chiang, J.C.H., Friedman, A.R., 2012. Extratropical Cooling, Interhemispheric Thermal Gradients, and Tropical Climate Change. Annual Review of Earth and Planetary Sciences 40, 383-412.

Cobb, K.M., Westphal, N., Sayani, H.R., Watson, J.T., Di Lorenzo, E., Cheng, H., Edwards, R.L., Charles, C.D., 2013. Highly Variable El Niño-Southern Oscillation Throughout the Holocene. Science 339, 67-70.

Consortium, P.k., 2013. Continental-scale temperature variability during the past two millennia. Nature Geosci 6, 339-346.

Crowley, T.J., (2000a). Causes of climate change over the past 1000 years. Science 289, 270-277.

Curry, R., Dickson, B., Yashayaev, I., 2003. A change in the freshwater balance of the Atlantic Ocean over the past four decades. Nature 426, 826-829.

Davis, B.A.S., Brewer, S., 2008. Orbital forcing and role of the latitudinal insolation/temperature gradient. Climate Dynamics 32, 143-165.

Ding, Y., Carton, J.A., Chepurin, G.A., Stenchikov, G., Robock, A., Sentman, L.T., Krasting, J.P., 2014. Ocean response to volcanic eruptions in Coupled Model Intercomparison Project 5 simulations. Journal of Geophysical Research: Oceans 119, $5622-5637$.

England, M.H., McGregor, S., Spence, P., Meehl, G.A., Timmermann, A., Cai, W., Gupta, A.S., McPhaden, M.J., Purich, A., Santoso, A., 2014. Recent intensification of wind-driven circulation in the Pacific and the ongoing warming hiatus. Nature Clim. Change 4, 222-227.

Fine, R.A., Lukas, R., Bingham, F.M., al., e., 1994. The western equatorial Pacific: A water mass crossroads. JOURNAL OF GEOPHYSICAL RESEARCH 99, 25,063025,080.

Forster, P., Ramaswamy, V., 2007. Changes in Atmospheric Constituents and in Radiative Forcing, In: Solomon, S., Qin, D., Manning, M., Chen, Z., Marquis, M., Averyt, K.B., Tignor, M., Miller, H.L. (Eds.), IPCC Fourth Assessment Report (AR4): Climate Change 2007: The Physical Science Basis, Cambridge University Press, Cambridge, United Kingdom and New York, NY, USA, , p. 996 pp. 
Francis, J.A., Vavrus, S.J., 2012. Evidence linking Arctic amplification to extreme 
Landrum, L., Otto-Bliesner, B.L., Wahl, E.R., Conley, A., Lawrence, P.J., Rosenbloom, N., Teng, H., 2013. Last Millennium Climate and Its Variability in CCSM4. Journal of Climate 26, 1085-1111.

Leduc, L., Schneider, R., Kim, J.-H., Lohmann, G., 2010. Holocene and Eemian sea surface temperature trends as revealed by alkenone and $\mathrm{Mg} / \mathrm{Ca}$ paleothermometry. Quaternary Science Reviews 29, 989-1004.

Levitus, S., Antonov, T.P., Boyer, S., Baranova, O.K., Garcia, H.E., Locarnini, R.A., Mishonov, A.V., Reagan, J.R., Seidov, D., Yarosh, E.S., Zweng, M.M., 2012. World ocean heat content and thermosteric sea level change (0-2000 m), 1955-2010. Geophys. Res. Lett. 39, 5.

Linsley, B.K., Rosenthal, Y., Oppo, D.W., 2010. Evolution of the Indonesian Throughflow and Western Pacific Warm Pool During the Holocene. Nature Geoscience 3, 578 - 583 doi:510.1038/ngeo1920.

Linsley, B.K., Wu, H.C., Dassié, E.P., Schrag, D.P., 2015. Decadal changes in South Pacific sea surface temperatures and the relationship to the Pacific decadal oscillation and upper ocean heat content. Geophysical Research Letters 42, 2358-2366.

Liu, Z., Alexander, M., 2007. 2007. Atmospheric bridge, oceanic tunnel, and global climatic teleconnections. . Reviews of Geophysics 45.

Liu, Z., Brady, E., Lynch-Stieglitz, J., 2003. Global ocean response to orbital forcing in the Holocene. Paleoceanography 18.

Liu, Z., Zhu, J., Rosenthal, Y., Zhang, X., Otto-Bliesner, B.L., Timmermann, A., Smith, R.S., Lohmann, G., Zheng, W., Elison Timm, O., 2014. The Holocene temperature conundrum. Proceedings of the National Academy of Sciences 111, E3501-E3505.

Luan, Y.-H., AU - Yu, Y.-Q., AU - Zheng, W.-P., 2016. Heat budget analysis in three typical warm periods simulated by FGOALS-s2. Atmospheric and Oceanic Science Letters 9, 7.

Mann, M.E., et al., 2008. Proxy-based reconstructions of hemispheric and global surface temperature variations over the past two millennia. Proceedings of the National Academy of Sciences of the United States of America, 105, 13252.

Mann, M.E., Zhang, Z., Hughes, M.K., Bradley, R.S., Miller, S.K., Rutherford, S., Ni, F., 2008. Proxy-based reconstructions of hemispheric and global surface temperature variations over the past two millennia. Proceedings of the National Academy of Sciences. 105: 13252-13257.

Marcott, S.A., Shakun, J.D., Clark, P.U., Mix, A.C., 2013. A Reconstruction of Regional and Global Temperature for the Past 11,300 Years. Science 339, 1198-1201.

Masson, V., Vimeux, F., Jouzel, J., al., e., 2000. Holocene Climate Variability in Antarctica Based on 11 Ice-Core Isotopic Records. Quaternary Research. 54, 348358.

Masson-Delmotte, V., Buiron, D., Ekaykin, A., Frezzotti, M., Gallée, H., Jouzel, J., Krinner, G., Landais, A., Motoyama, H., Oerter, H., Pol, K., Pollard, D., Ritz, C., Schlosser, E., Sime, L.C., Sodemann, H., Stenni, B., Uemura, R., Vimeux, F., 2011. A comparison of the present and last interglacial periods in six Antarctic ice cores. Clim. Past 7, 397-423.

Max, L., Lembke-Jene, L., Riethdorf, J.R., Tiedemann, R., Nürnberg, D., Kühn, H., Mackensen, A., 2014. Pulses of enhanced North Pacific Intermediate Water 
ventilation from the Okhotsk Sea and Bering Sea during the last deglaciation. Clim. Past 10, 591-605.

Meehl, G.A., Hu, A., Arblaster, J.M., Fasullo, J., Trenberth, K.E., 2013. Externally Forced and Internally Generated Decadal Climate Variability Associated with the Interdecadal Pacific Oscillation. Journal of Climate 26, 7298-7310.

Miller, G.H., Geirsdóttir, Á., Zhong, Y., Larsen, D.J., Otto-Bliesner, B.L., Holland, M.M., Bailey, D.A., Refsnider, K.A., Lehman, S.J., Southon, J.R., Anderson, C., Björnsson, H., Thordarson, T., 2012. Abrupt onset of the Little Ice Age triggered by volcanism and sustained by sea-ice/ocean feedbacks. Geophysical Research Letters 39.

Moberg, A., Sonechkin, D.M., Holmgren, K., Datsenko, N.M., Karlen, W., 2005. Highly variable Northern Hemisphere temperatures reconstructed from low- and highresolution proxy data. Nature 433, 613-617.

Moberg, A.D., et al., 2005. Highly variable northern hemisphere temperature reconstructed from low- and high-resolution proxy data. Nature 433, 613.

Morley, A., Rosenthal, Y., deMenocal, P., 2014. Ocean-atmosphere climate shift during the mid-to-late Holocene transition. Earth and Planetary Science Letters 388, 18-26.

Morley, A., Schulz, M., Rosenthal, Y., Mulitza, S., Paul, A., Rühlemann, C., 2011. Climate variability and signal propagation via North Atlantic central water formation during the Late Holocene. Earth Planet. Sci. Lett. 308, 161 - 171.

Morrison, A.K., Griffies, S.M., Winton, M., Anderson, W.G., Sarmiento, J.L., 2016. Mechanisms of Southern Ocean Heat Uptake and Transport in a Global Eddying Climate Model. Journal of Climate, 2059-2075.

Mulvaney, R., Abram, N.J., Hindmarsh, R.C.A., Arrowsmith, C., Fleet, L., Triest, J., Sime, L.C., Alemany, O., Foord, S., 2012. Recent Antarctic Peninsula warming relative to Holocene climate and ice-shelf history. Nature 489, 141-144.

Newman, M., Alexander, M., Ault, T., Cobb, K., Deser, C., Di Lorenzo, E., Mantua, N., A. Miller, Minobe, S., H. Nakamura, Schneider, N., Vimont, D., Phillips, A., Scott, J., Smith, C., 2016. The Pacific Decadal Oscillation, Revisited. . J. Climate. 29: 43994427.

Nürnberg, D., Böschen, T., Doering, K., Mollier-Vogel, E., Raddatz, J., Schneider, R., 2015. Sea surface and subsurface circulation dynamics off equatorial Peru during the last $\sim 17$ kyr. Paleoceanography 30, 2014PA002706.

Oppo, D.W., Rosenthal, Y., Linsley, B.K., 2009. 2,000-year-long temperature and hydrology reconstructions from the western Pacific warm pool. Nature 460, 11131116.

Orsi, A.J., Cornuelle, B.D., Severinghaus, J.P., 2012. Little Ice Age cold interval in West Antarctica: Evidence from borehole temperature at the West Antarctic Ice Sheet (WAIS) Divide. Geophys. Res. Lett. 39, L09710, doi:10.1029/2012GL051260

Pahnke, K., Sachs, J.P., 2006. Sea surface temperatures of southern midlatitudes 0-160 kyr B.P. Paleoceanography 21.

Pahnke, K., Zahn, R., 2005. Southern Hemisphere Water Mass Conversion Linked with North Atlantic Climate Variability. Science 307, 1741-1746.

Peck, V.L., Allen, C.S., Kender, S., McClymont, E.L., Hodgson, D.A., 2015. Oceanographic variability on the West Antarctic Peninsula during the Holocene and 
855

856

857

858

859

860

861

862

863

864

865

866

867

868

869

870

871

872

873

874

875

876

877

878

879

880

881

882

883

884

885

886

887

888

889

890

891

892

893

894

895

896

897

898

899

the influence of upper circumpolar deep water. Quaternary Science Reviews 119, 5465.

Pena, L.D., Cacho, I., Calvo, E., Pelejero, C., Eggins, S., Sadekov, A., 2008. Characterization of contaminant phases in foraminifera carbonates by electron microprobe mapping. Geochem. Geophys. Geosys. 9, doi:10.1029/2008GC002018.

Pena, L.D., Goldstein, S.L., Hemming, S.R., Jones, K.M., Calvo, E., Pelejero, C., Cacho, I., 2013. Rapid changes in meridional advection of Southern Ocean intermediate waters to the tropical Pacific during the last $30 \& \# \mathrm{xa} 0 ; \mathrm{kyr}$. Earth and Planetary Science Letters 368, 20-32.

Rella, S.F., Uchida, M., 2014. A Southern Ocean trigger for Northwest Pacific ventilation during the Holocene? Scientific Reports 4, 4046.

Rhodes, R.H., Bertler, N.A.N., Baker, J.A., Steen-Larsen, H.C., Sneed, S.B., Morgenstern, U., Johnsen, S.J., 2012. Little Ice Age climate and oceanic conditions of the Ross Sea, Antarctica from a coastal ice core record. Clim. Past 8, 1223-1238.

Roemmich, D., Church, J., Gilson, J., Monselesan, D., Sutton, P., Wijffels, S., 2015. Unabated planetary warming and its ocean structure since 2006. Nature Clim. Change 5, 240-245.

Roemmich, D., Gilson, J., Davis, R., Sutton, P., Wijffels, S., Riser, S., 2007. Decadal Spinup of the South Pacific Subtropical Gyre. Journal of Physical Oceanography 37, 162-173.

Rosenthal, Y., Linsley, B.K., Oppo, D.W., 2013. Pacific Ocean Heat Content During the Past 10,000 Years. Science 342, 617-621.

Rosenthal, Y., Morley, A., Barras, C., Katz, M., Jorissen, F., Reichart, G.-J., Oppo, D.W., Linsley, B.K., 2011. Temperature calibration of $\mathrm{Mg} / \mathrm{Ca}$ ratios in the intermediate water benthic foraminifer Hyalinea balthica. Geophys. Geochem. Geosys 12, doi:10.1029/2010GC003333.

Russell, J.L., Dixon, K.W., Gnanadesikan, A., Stouffer, R.J., Toggweiler, J.R., 2006. The Southern Hemisphere Westerlies in a Warming World: Propping Open the Door to the Deep Ocean. Journal of Climate 19, 6382-6390.

Schleussner, C.F., Feulner, G., 2013. A volcanically triggered regime shift in the subpolar North Atlantic Ocean as a possible origin of the Little Ice Age. Clim. Past 9, 13211330.

Schmidt, G.A., Jungclaus, J.H., Ammann, C.M., Bard, E., Braconnot, P., Crowley, T.J., Delaygue, G., Joos, F., Krivova, N.A., Muscheler, R., Otto-Bliesner, B.L., Pongratz, J., Shindell, D.T., Solanki, S.K., Steinhilber, F., Vieira, L.E.A., 2012. Climate forcing reconstructions for use in PMIP simulations of the Last Millennium (v1.1). Geosci. Model Dev. 5, 185-191.

Shevenell, A.E., Ingalls, A.E., Domack, E.W., Kelly, C., 2011. Holocene Southern Ocean surface temperature variability west of the Antarctic Peninsula. Nature 470, 250-254.

Spero, H.J., Lea, D.W., 2002. The Cause of Carbon Isotope Minimum Events on Glacial Terminations. Science 296, 522-525.

Steig, E.J., Morse, D.L., Waddington, E.D., Stuiver, M., Grootes, P.M., Mayewski, P.A., Twickler, M.S., Whitlow, S.I., 2000. Wisconsinan and Holocene Climate History from an Ice Core at Taylor Dome, Western Ross Embayment, Antarctica.

Geografiska Annaler: Series A, Physical Geography 82, 213-235. 
Stenchikov, G., Delworth, T.L., Ramaswamy, V., Stouffer, R.J., Wittenberg, A., Zeng, F., 2009. Volcanic signals in oceans. Journal of Geophysical Research: Atmospheres 114.

Stott, L., Cannariato, K., Thunell, R., Haug, G.H., Koutavas, A., Lund, L., 2004. Decline of surface temperature an salinity in the western tropical Pacific Ocean in the Holocene epoch. Nature 431, 56-59.

Stouffer, R.J., Yin, J., Gregory, J.M., Dixon, K.W., Spelman, M.J., Hurlin, W., Weaver, A.J., Eby, M., Flato, G.M., Hasumi, H., Hu, A., Jungclaus, J.H., Kamenkovich, I.V., Levermann, A., Montoya, M., Murakami, S., Nawrath, S., Oka, A., Peltier, W.R., Robitaille, D.Y., Sokolov, A., Vettoretti, G., Weber, S.L., 2006. Investigating the Causes of the Response of the Thermohaline Circulation to Past and Future Climate Changes. Journal of Climate 19, 1365-1387.

Talley, L.D., 1991. An Okhotsk Sea water anomaly: implications for ventilation in the North Pacific. Deep Sea Research 38, 171-190.

Talley, L.D., Sprintall, J., 2005. Deep expression of the Indonesian Throughflow: Indonesian Intermediate Water in the South Equatorial Current. J. Geophys. Res. 110.

Thompson, D.M., Cole, J.E., Shen, G.T., Tudhope, A.W., Meehl, G.A., 2015. Early twentieth-century warming linked to tropical Pacific wind strength. Nature Geosci 8, 117-121.

Thompson, D.W.J., Solomon, S., Kushner, P.J., England, M.H., Grise, K.M., Karoly, D.J., 2011. Signatures of the Antarctic ozone hole in Southern Hemisphere surface climate change. Nature Geosci 4, 741-749.

Timmermann, A., Sachs, J., Timm, O.E., 2014. Assessing divergent SST behavior during the last $21 \mathrm{ka}$ derived from alkenones and G. ruber- $\mathrm{Mg} / \mathrm{Ca}$ in the equatorial Pacific. Paleoceanography 29, 680-696.

Toggweiler, J.R., Russell, J.L., Carson, S.R., 2006. Midlatitude westerlies, atmospheric $\mathrm{CO}_{2}$, and climate change during the ice ages. Paleoceanography $21, \mathrm{n} / \mathrm{a}-\mathrm{n} / \mathrm{a}$.

Trenberth, K.E., Fasullo, J.T., 2013. An apparent hiatus in global warming? Earths Future 1, 19-32.

Trenberth, K.E., Fasullo, J.T., Balmaseda, M.A., 2014. Earth's Energy Imbalance. Journal of Climate 27, 3129-3144.

Tsuchiya, M., 1981. The Origin of the Pacific Equatorial $13^{\circ} \mathrm{C}$ Water. Journal of Physical Oceanography 11, 794-812.

Urban, F.E., Cole, J.E., Overpeck, J.T., 2000. Influence of mean climate change on climate variability from a 155-year tropical Pacific coral record. Nature 407, 989-993.

Verleyen, E., Hodgson, D.A., Sabbe, K., Cremer, H., Emslie, S.D., Gibson, J., Hall, B., Imura, S., Kudoh, S., Marshall, G.J., McMinn, A., Melles, M., Newman, L., Roberts, D., Roberts, S.J., Singh, S.M., Sterken, M., Tavernier, I., Verkulich, S., de Vyver, E.V., Van Nieuwenhuyze, W., Wagner, B., Vyverman, W., 2011. Post-glacial regional climate variability along the East Antarctic coastal margin-Evidence from shallow marine and coastal terrestrial records. Earth-Science Reviews 104, 199-212. Woollings, T., Hoskins, B., Blackburn, M., Berrisford, P., 2008. A New Rossby WaveBreaking Interpretation of the North Atlantic Oscillation. Journal of the Atmospheric Sciences 65, 609-626.

Xue, Y., Smith, T.M., Reynolds, R.W., 2003. Interdecadal Changes of 30-Yr SST Normals during 1871-2000. Journal of Climate 16, 1601-1612. 
946 Zenk, W., et al., 2005. Pathways and variability of the Antarctic Intermediate Water in

947 the western equatorial Pacific Ocean. Progress in Oceanography 67, 245-281

948 


\section{Figure Captions}

950

951 Figure 1: The last 60 years carbon emissions are shown (A) global surface temperature

952 anomalies are compared with global emissions of $\mathrm{CO}_{2}$; (B) changes in World Ocean

953 OHC at different depth intervals; (C) changes in $\mathrm{OHC}$ at different ocean basins.

954 Figure 2: Map of sites used for reconstructing surface and intermediate water

955 temperatures. Also shown are the general trajectories of the modern intermediate

956 water masses (LCDW= Lower Circumpolar Deep Water, UCDW= Upper

957 Circumpolar Deep Water; SAMW= Sub-Antarctic Mode Water; AAIW= Antarctic

958 Intermediate Water; NPIW= North Pacific Intermediate Water; ITF=Indonesian

959 Throughflow). SST records (shown in green triangles) are from Marcott et al.,

960 (2013). IWT records (shown in numbered circles) are from Rosenthal et al. 2013

961 (1\&2), Kalansky et al. 215 (3\&4) Morley et al. 2014 (5), and Morley et al. 2011 (6)

962 Figure 3: Records of Holocene $\mathrm{Mg} / \mathrm{Ca}$-derived SST anomalies (a-c) are compared with

963 IWT anomalies (d-g) from the WPWP, eastern Pacific and North Atlantic.

964 Figure 4: Southern Hemisphere high latitude temperature and precipitation

965 records plotted along with Uvigerina and $N$. dutertrei temperature anomalies

966 from the EEP. (A) Dec-Feb and June-August insolation at $55^{\circ} \mathrm{S}$ latitude (B)

967 Antarctic temperature records from and Empirical Orthogonal Function (EOF) of

9685 ice core $\delta^{18} 0$ records (black line) (Masson-Delmotte et al., 2011) and James Ross

969 ice core $\delta D$ (blue line)(Mulvaney et al., 2012) (C) Ocean temperature records (0-

$970150 \mathrm{~m}$ ) from the Pacific sector of the Southern Ocean (black line) (Shevenell et

971 al., 2011), SST from MD97 $2021\left(45^{\circ} \mathrm{S}, 174^{\circ} \mathrm{E}\right.$ ) (red line) (Pahnke and Sachs,

972 2006) and SST from ODP $1233\left(41^{\circ} \mathrm{S}, 74^{\circ} \mathrm{W}\right.$ ) (blue line) (Kaiser et al., 2005) (D)

$973 \quad C_{\text {org }}$ and siliciclastic accumulation rates as proxies for precipitation from the

974 Chilean Fjords $\left(53^{\circ} \mathrm{S}\right.$ ) (Lamy et al., 2010) (E) N. dutertrei (blue) and Uvigerina

975 (black) temperature reconstructions from the EEP (Kalansky et al., 2015). Note

976 the different temperature scales on the axes 
977 Figure 5: Common Era temperature anomalies. (a) Average surface anomalies based on 978 the reconstructions of (Mann et al., 2008; Moberg et al., 2005) and (Oppo et al., 979 2009). (b) IWT anomalies in intermediate water depth ( 500-900 m) cores from 980 Indonesia (Rosenthal et al., 2013). (c) IWT anomalies in intermediate water depth $981 \quad(\sim 1000 \mathrm{~m})$ core from the northeastern Atlantic (Morley et al., 2011).

982 Figure 6: (top) Comparison of South Pacific 0-700m Ocean Heat Content (in 10^22 983 Joules; Levitus et al., 2012) to (middle) Fiji, Tonga, Rarotonga (FTR) coral Sr/Ca 984 SST reconstruction of Linsley et al. (2015) and (bottom) Fanning, Palmyra, Maiana 985 (FPM) equatorial coral $\delta^{18} \mathrm{O}$ composite (defined in Linsley et al., 2015). The number 986 of corals comprising each average is indicated. Fanning and Palmyra data from Cobb 987 et al. (2013) and Maiana data from Urban et al. (2000).

988 Figure 7: Reconstructed anomalies in Pacific $\mathrm{OHC}$ in the $0-700 \mathrm{~m}$ depth interval for the 989 early-Holocene, mid-Holocene, MWP and LIA periods. Reconstructed anomalies are 990 calculated relative to the reference period of 1965-1970 CE (Rosenthal et al., 2013). 
Table 1: Acronyms used in the paper

\begin{tabular}{|ll|}
\hline AAIW & Antarctic Intermediate Water \\
\hline AMOC & Atlantic Meriodional Overtruning Circulation \\
\hline EEP & Eastern Equatorial Pacific \\
\hline EGC & East Greenland Current \\
\hline ENACW & Eastern North Atlantic Central Waters \\
\hline FTR & Fiji, Tonga and Rarotonga \\
\hline GHG & Greenhouse Gas \\
\hline HMT & Holocene Thermal Maximum \\
\hline ITF & Indonesian Throughflow \\
\hline IWT & intermediate water temperature \\
\hline LIA & Little Ice Age \\
\hline LTG & latitudinal temperature gradients \\
\hline MCA & Medieval Climate Anomaly \\
\hline NPIW & North Pacific Intermediate Water \\
\hline OHC & Ocean Heat Content \\
\hline PDO & Pacific Decadal Oscillation \\
\hline SAF & Sub Arctic Front \\
\hline SAMW & Subantarctic Mode Water \\
\hline SPG & Sub polar Gyre \\
\hline Subtropical Front \\
\hline SW
\end{tabular}


Figure
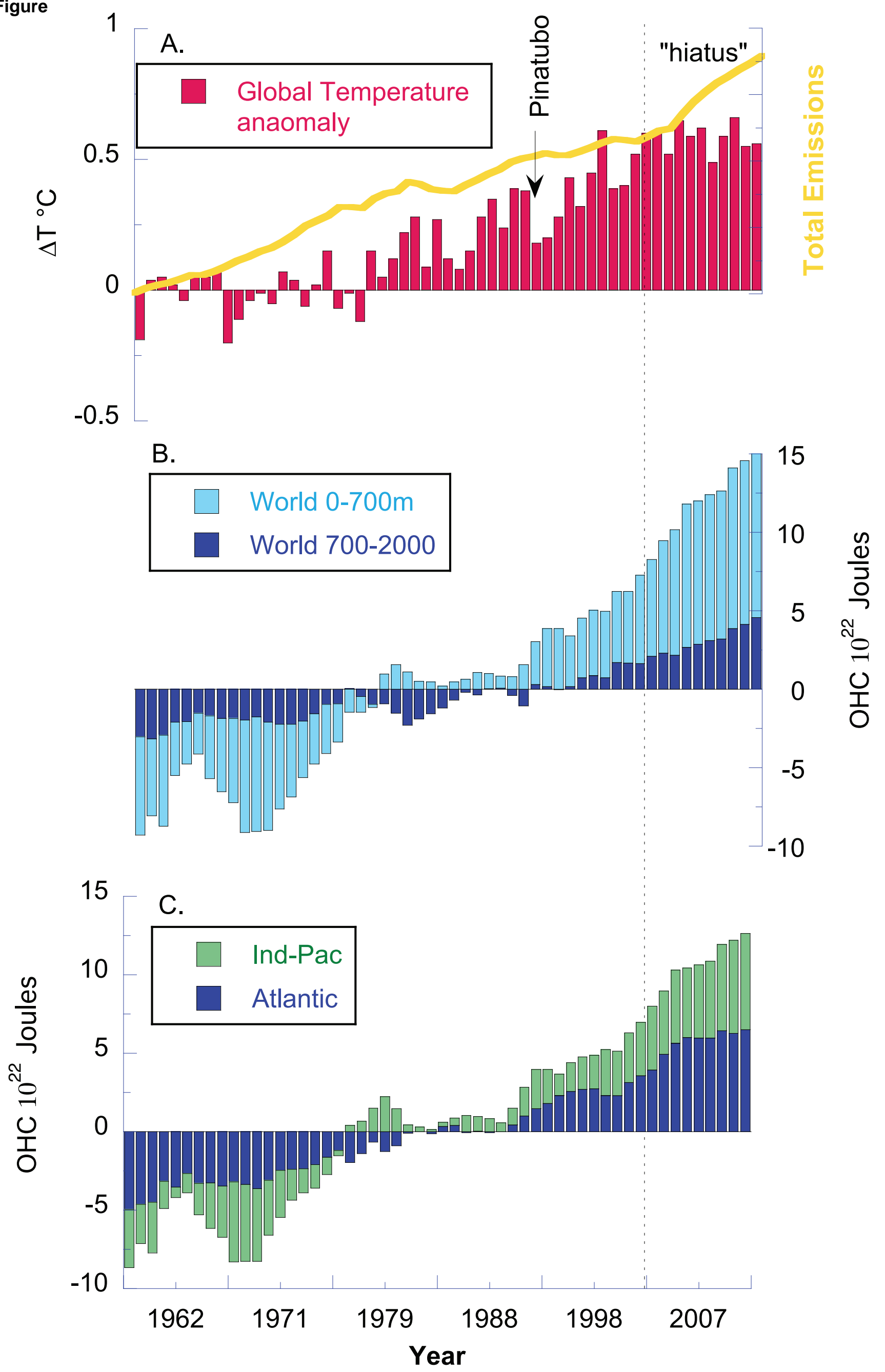


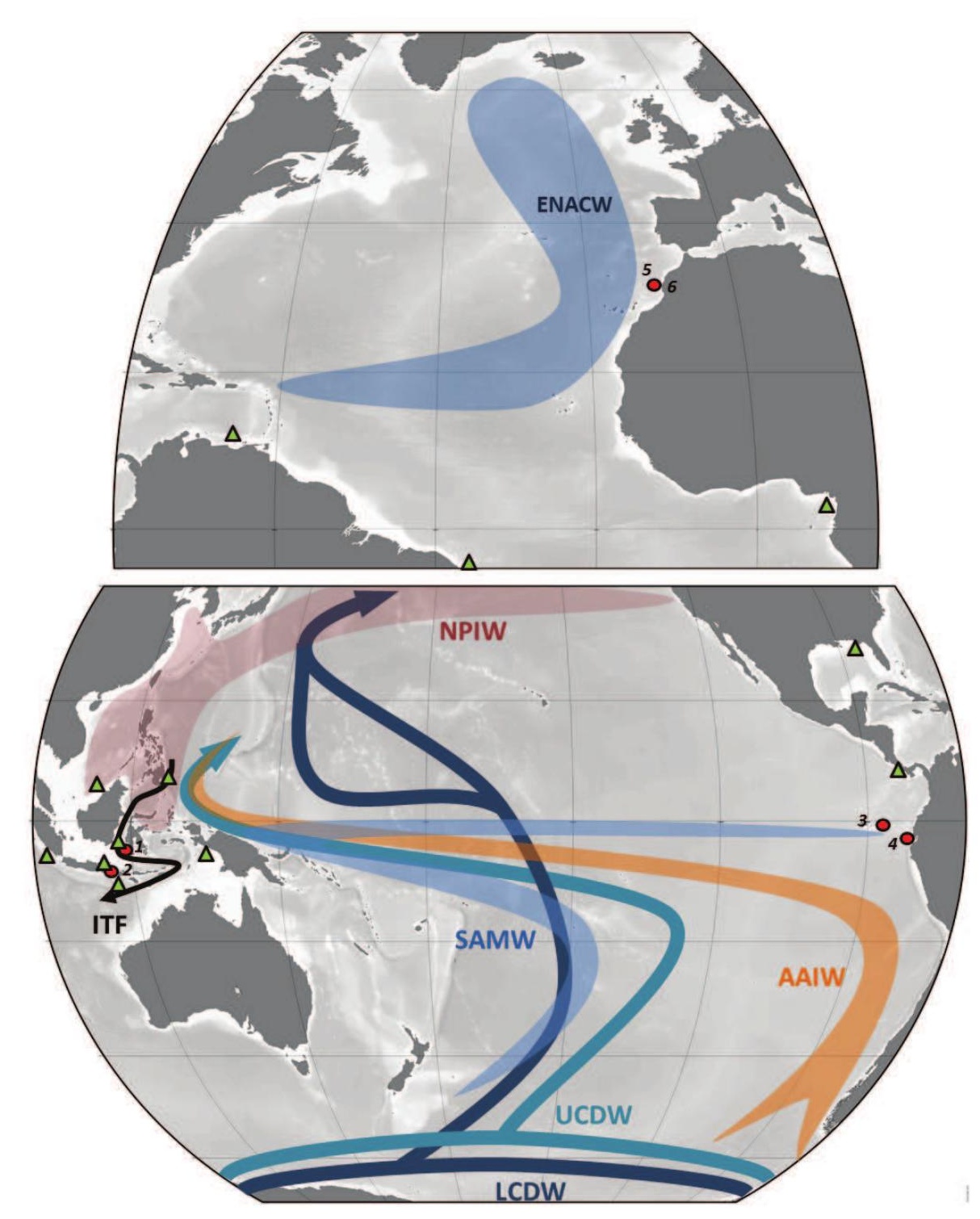

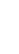

Figure 

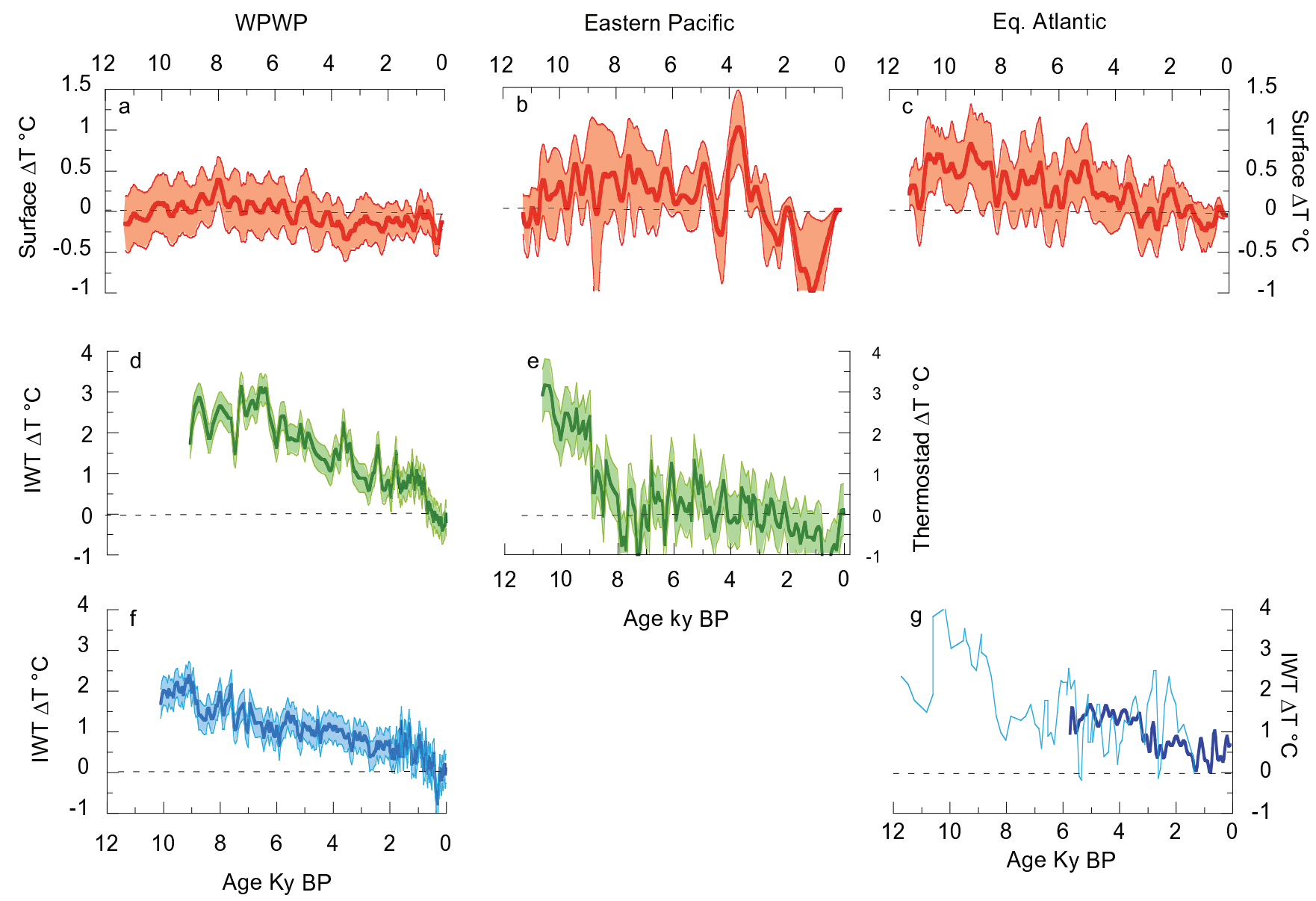

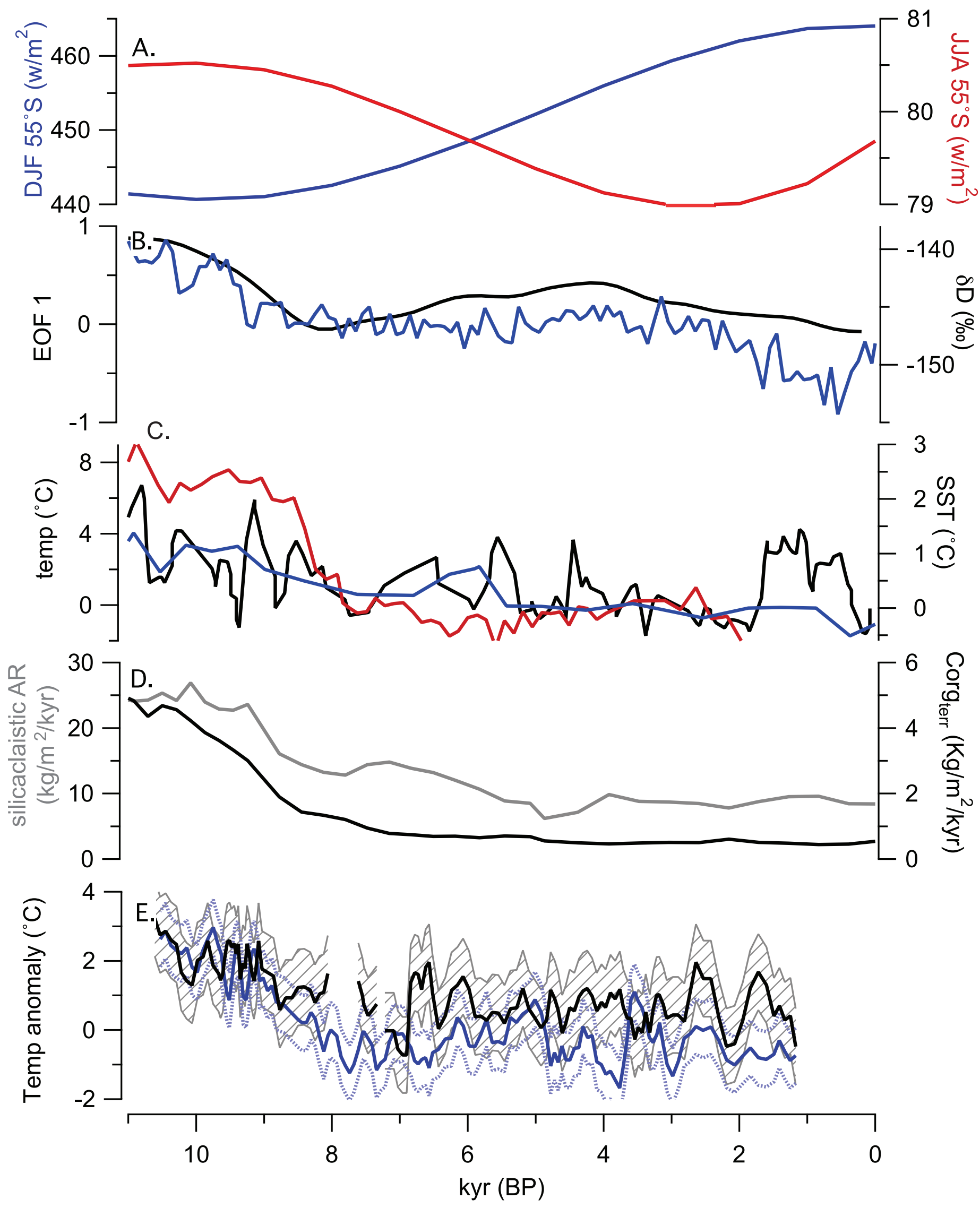

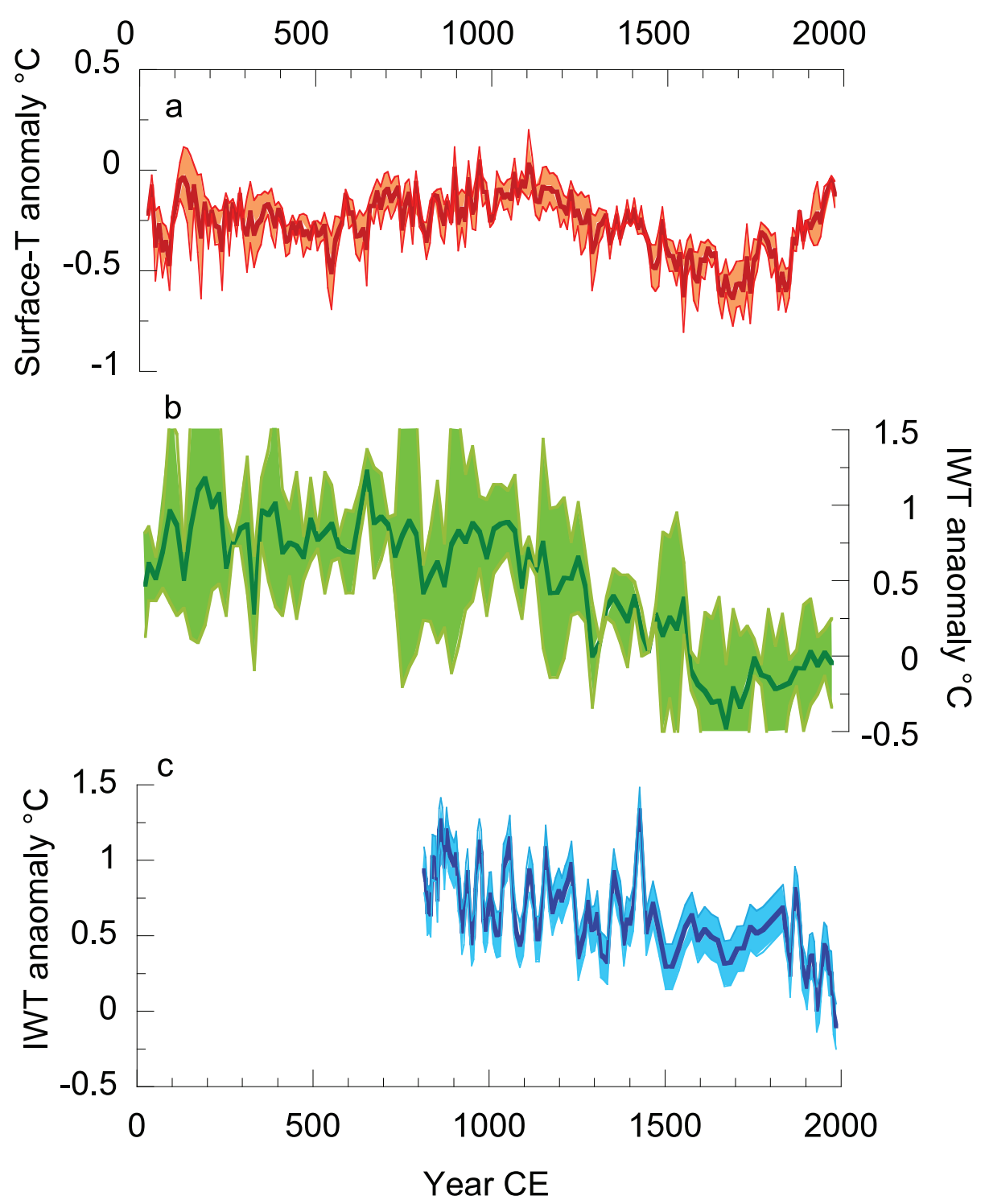


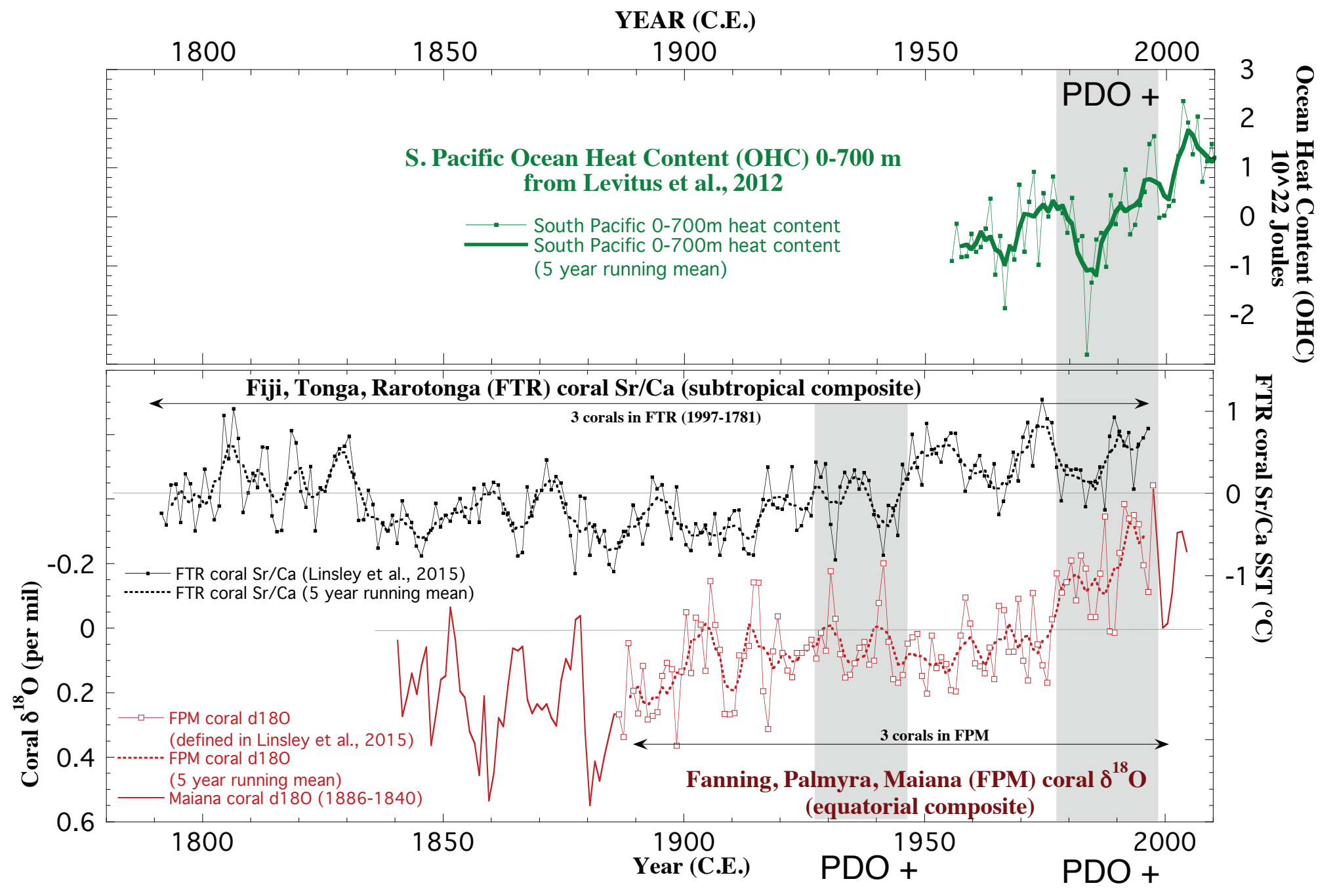




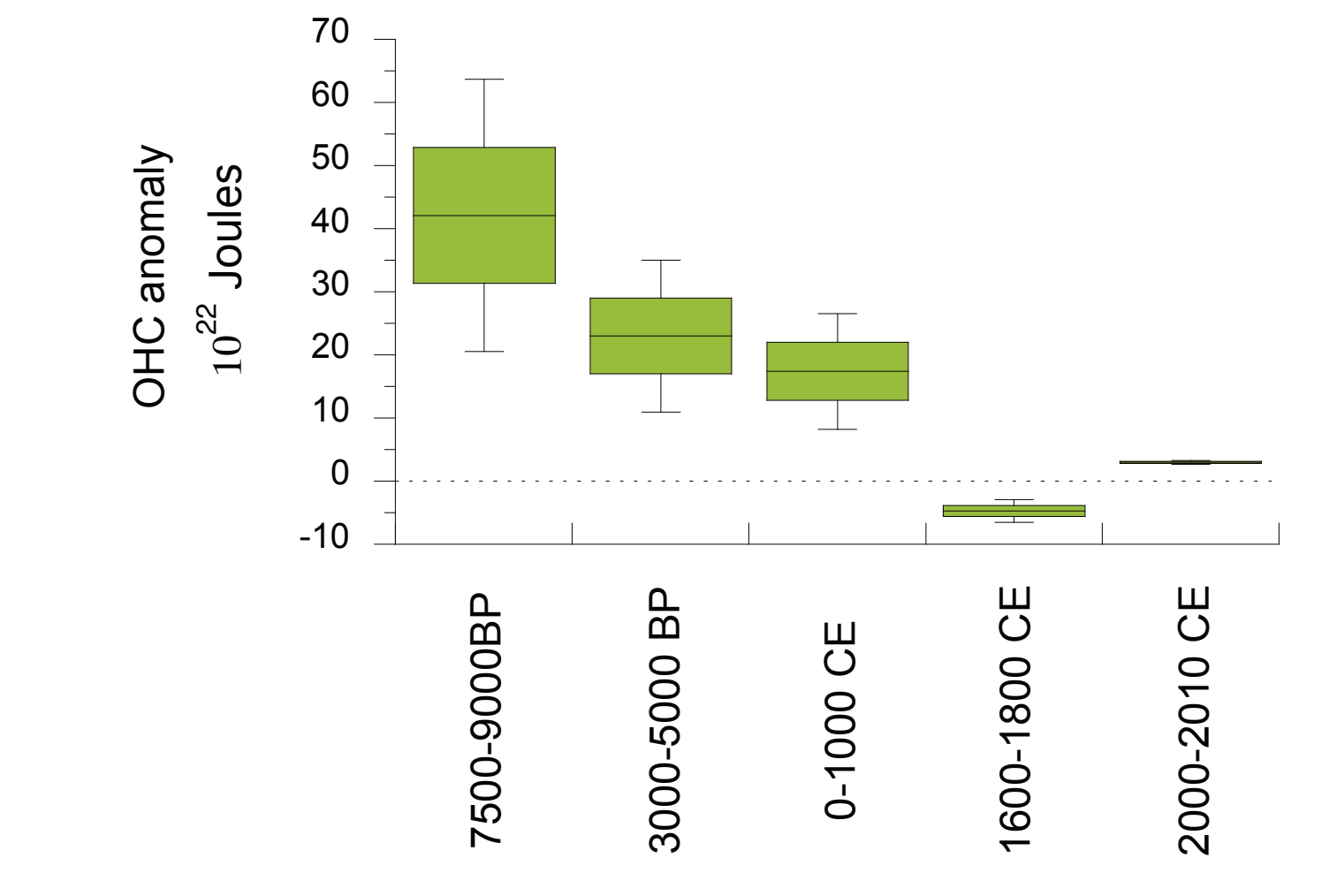

Figure

列

Figure

$\sqrt{20}+2$

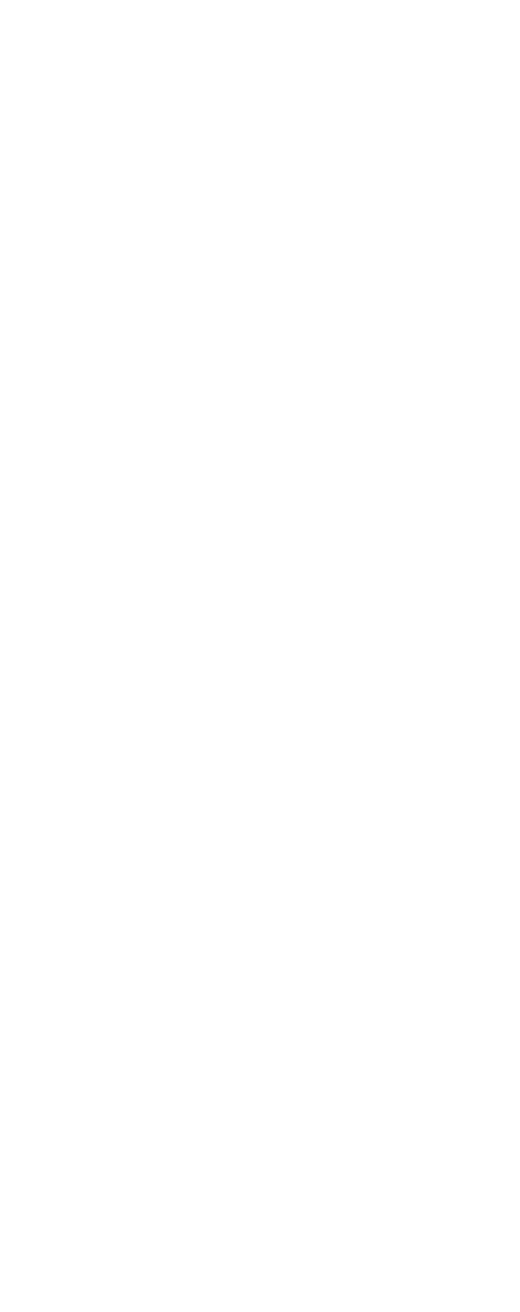

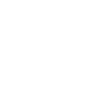

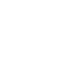

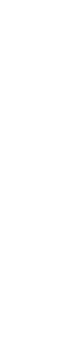

(

(

(

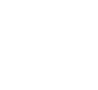

(

.

.

(

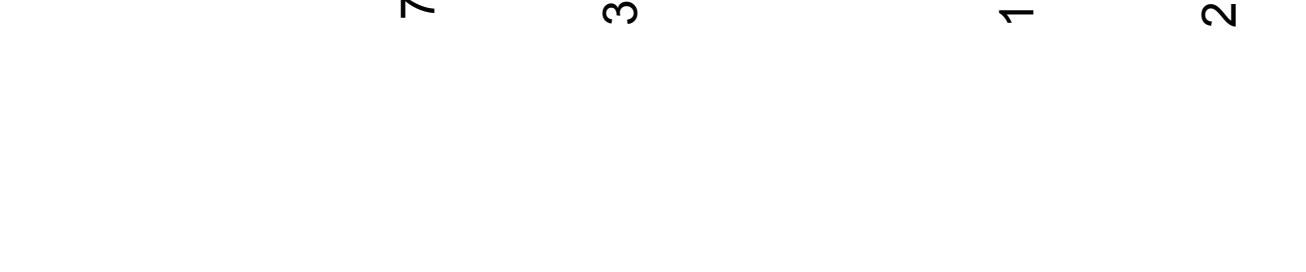

